The impact of EU-funded direct subsidies on several dimensions of firm performance in Portugal: 2008-2015

Ricardo Mamede

Henrique Pereira

Dezembro 2018

WP n. ${ }^{\circ} 2018 / 08$

DOCUMENTO DE TRABALHO WORKING PAPER

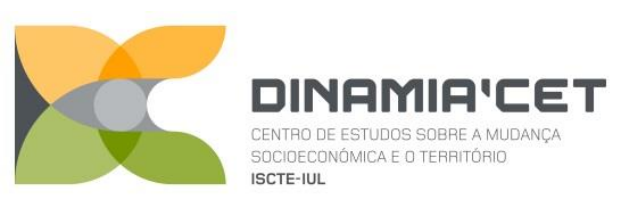

ISCTE IUL

Instituto Universitário de Lisboa 
The impact of EU-funded direct subsidies on several dimensions of firm performance in Portugal: 2008-2015

Ricardo Mamede

Henrique Pereira

Dezembro 2018

WP n. ${ }^{\circ} 2018 / 08$

DOCUMENTO DE TRABALHO WORKING PAPER

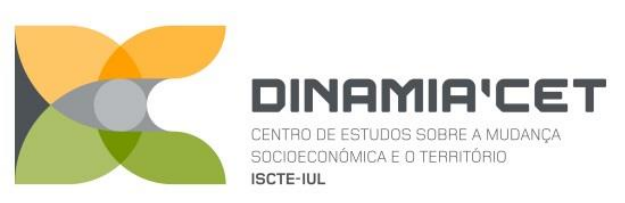

ISCTE IUL

Instituto Universitário de Lisboa 


\section{The impact of EU-funded direct subsidies on several dimensions of firm performance in Portugal: 2008-2015}

Ricardo Mamede*

Henrique Pereira**

WP n. $\circ 2018 / 08$

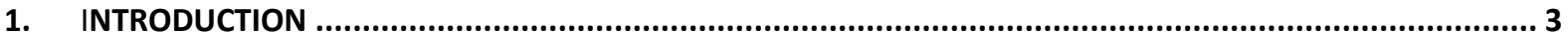

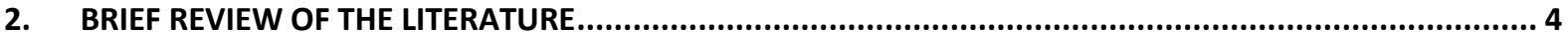

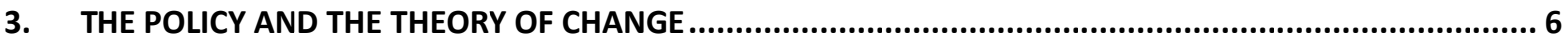

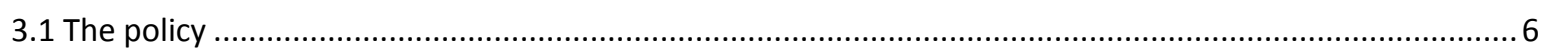

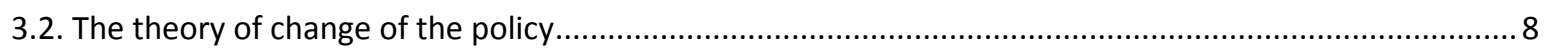

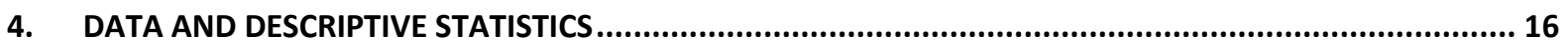

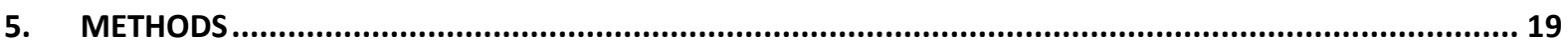

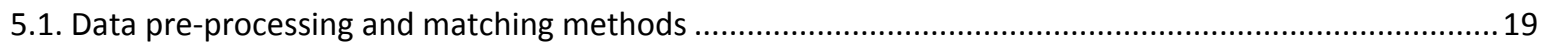

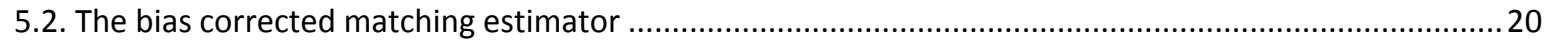

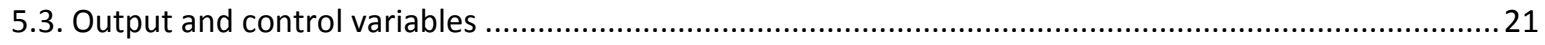

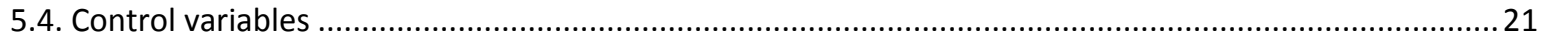

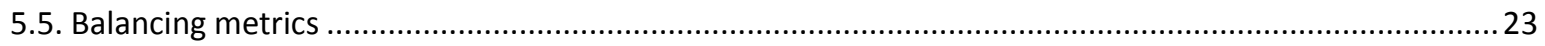

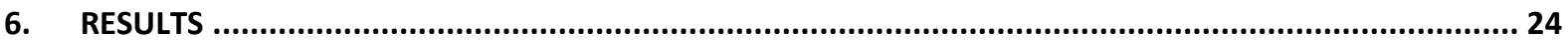

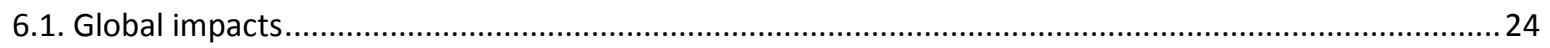

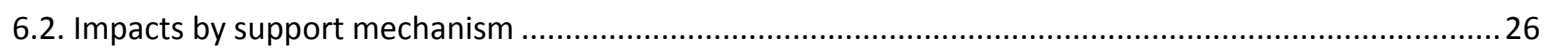

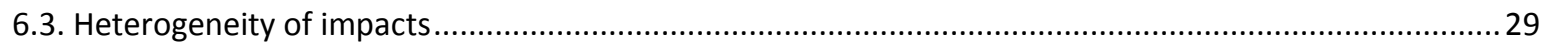

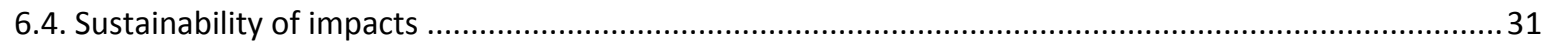

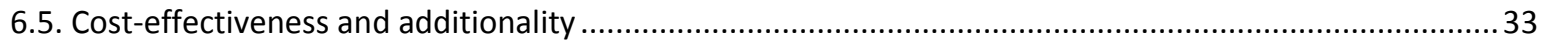

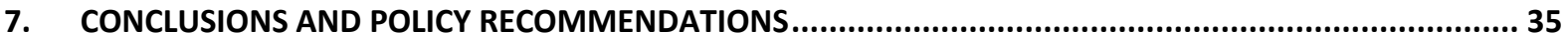

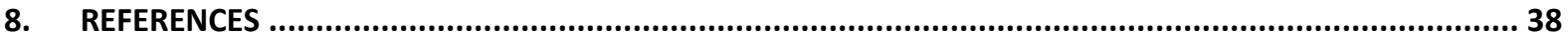

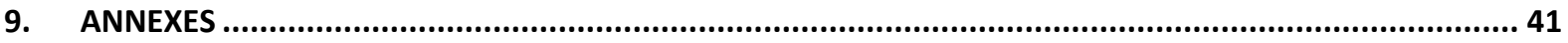

* Instituto Universitário de Lisboa (ISCTE-IUL), DINÂMIA'CET-IUL, Lisboa, Portugal.

** DINÂMIA'CET-IUL, Lisboa, Portugal. 


\title{
The impact of EU-funded direct subsidies on several dimensions of firm performance in Portugal: 2008-2015
}

\begin{abstract}
This paper assesses the impact of SI QREN - a set of enterprise support mechanisms that were in place in Portugal between 2007 and 2013 - on firm performance. For this purpose, we used an unprecedented set of firm-level information, gathered from different institutional sources. These data allowed to control for several determinants of performance that are usually ignored in similar studies, and to assess the impact of the policy in various dimensions of enterprise performance, including: investment, financial situation, human capital, innovation, internationalization, firm growth, competitiveness, eco-efficiency, job quality, intra-firm income distribution, and gender equality. In order to address the selection bias that is inherent to the policy under analysis we estimated the impacts using the bias corrected matching estimator put forward by Abadie and Imbens $(2002,2011)$, producing results based on both the Propensity-Score Matching and Malahanobis Distance Matching methods, for robustness purposes. Our results suggest that SI QREN accomplished its main policy goals, as they are identified in the theory of change of the policy. Generally speaking, the impacts of SI QREN remain positive and statistically significant in the mid-term, after the supported projects have been completed. We also find that SI QREN is less effective in inducing additional investment in firms that have easier access to external finance.
\end{abstract}

Keywords: Enterprise support mechanisms; EU Cohesion Policy; Counterfactual Impact Evaluation JEL codes: C14, H71, L53

DINÂMIA'CET - IUL, Centro de Estudos sobre a Mudança Socioeconómica e o Território

do Instituto Universitário de Lisboa (ISCTE-IUL)

Sala 2W4 - D | ISCTE-IUL - Av. das Forças Armadas

1649-026 Lisboa, PORTUGAL

Tel. (+351) 210464031 / 210464197 | E-mail: dinamia@iscte-iul.pt | www.dinamiacet.iscte-iul.pt 


\section{INTRODUCTION}

This paper assesses the impact of SI QREN ${ }^{1}$, a set of enterprise of support mechanisms funded by the EU Cohesion Policy in Portugal in 2007-2015, under the National Strategic Reference Framework 2007-2013 (NSRF).

Although SI QREN explicitly intended to produce effects at different scales (individual firms, industries, clusters, regions, the whole country), the scope of this evaluation is limited to the analysis of policy impacts on firm performance, which is directly affected by the interventions concerned.

The impacts were estimated using alternative matching methods. We focus our efforts on estimating the feasible average treatment effect on the treated (FATT). "Feasible" because the estimates refer to the sub-sample of treated units for which it was possible to conceive a reasonable control, assuring the internal validity of results; no extrapolation is made nor intended. Our goal was to achieve an estimation that is as consistent and efficient as possible (with priority given to consistency), while maintaining a large sample size to bring the support of asymptotic knowledge of the estimator to analysis robustness. We follow Abadie and Imbens' (2002, 2006, 2011) bias corrected matching estimator for average treatment effects and heteroscedasticity robust variance estimation.

The dimensions of firm performance under analysis include: the internationalization of companies; productivity; job creation; human capital; R\&D; and competitiveness. These dimensions are explicitly mentioned in the regulations as SI QREN's core goals. In addition, this study assesses the impact of SI QREN on other relevant policy goals, including: eco-efficiency; gender equality; job quality; and intra-firm income distribution. This research also addresses the heterogeneity of the impacts of the policy, which may vary according to the characteristics of the beneficiaries and to the context in which the policy was implemented.

The report is organized as follows. Section 2 presents a brief review of the literature on the impact of public investment subsidies on firm performance. Section 3 presents the policy under analysis and discusses the underlying theory of change, which guided our choices regarding the dimensions of firm performance to analyse. Section 4 describes the available data and presents some descriptive statistics. Section 5 deals with the methods used to estimate the impacts. Section 6 presents the main results of the project, and Section 7 concludes and puts forward some policy recommedations.

\footnotetext{
${ }^{1}$ The acronym in Portuguese stands for "Sistemas de Incentivos do QREN", literally, the incentive systems of the National Strategic Reference Framework (NSRF).

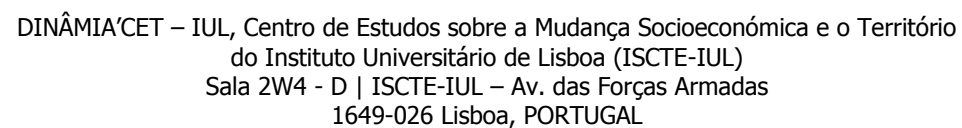




\section{BRIEF REVIEW OF THE LITERATURE}

Our research relates to previous efforts made at the European level to assess the impact of various enterprise support policies in different countries and time-periods. Those efforts include evaluation studies that were published as non-academic reports (for a review of these see Mouqué, 2012), as well as research papers published in academic journals (for a review see Cerqua, 2014).

The literature on impact assessment of firm support policies in Europe varies significantly with regard to the data, output and control variables, and the methods used ${ }^{2}$.

For example, Bia \& Mattei (2012) assess the impact of financial aid on the employment of companies located in the Italian region of Piedmont in the early 2000s, using propensity Score Matching (PSM) to adjust for differences in a set of variables observed in the pre-support period to construct an adequate control group. Bondonio \& Greenbaum (2006) implemented a parametric differences-indifferences (DiD) model to calculate the employment impact of EU-funded incentives in northern and central Italy in the late 1990s. Bronzini \& de Blasio (2006) use a similar method to analyse the effect of public policies on companies located in the regions of southern Italy during the same period. Bernini \& Pellegrini (2011) used a combination of matching and DiD methods to extend the analysis of Italian policies supported by the EU until the mid-2000s, while Cerqua \& Pellegrini (2014) reassessed the same business support mechanism analysed in Bronzini \& Blasio (2006) and Bernini \& Pellegrini (2011) using the Regression Discontinuity Design (RDD), exploring the discontinuities in the process of granting support (using non treated applicants as a control group). Focusing on the United Kingdom, Criscuolo et al. (2012) studied the effects of the Regional Selective Assistance program from the mid-1980s to the mid-2000s, using a combination of instrumental variables and fixed effects at the enterprise level. In Finland, Koski \& Pajarinen (2013) studied the effect of investment support and other subsidies granted to SMEs during the 2000s, applying both instrumental variables and DiD approaches. Bondonio \& Martini (2012) analysed the impact and cost-effectiveness of investment support in Italy using CEM combined with DiD.

A methodological approached similar to the one followed by Bondonio \& Martini (2012) was used by Mamede et al. (2013) and Bondonio et al. (2016) to assess the impact of firm support policies that were in force in Portugal in the early 2000s.

\footnotetext{
${ }^{2}$ Imbens \& Wooldridge (2009) and Imbens \& Rubin (2015) provide reviews of the most common methods of causal inference used in this type of analysis.

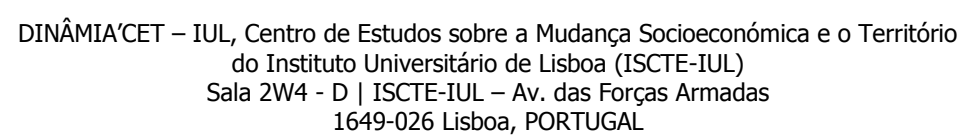


The present research differs from other studies both with regard to the methods used, the data that were available for research, and scope of analysis. As will be discussed later on, the volume and diversity of data led to the consideration of a wide variety of output and control variables, leading to more adequate identification of control groups. It also allowed for a deeper analysis of the heterogeneity of impacts. 


\section{THE POLICY AND THE THEORY OF CHANGE}

\subsection{The policy}

SI QREN, a set of enterprise support mechanisms in force until 2015, is the main policy instrument to promote business competitiveness in Portugal. In the context of the NSRF 2007-2013, SI QREN supported nearly 10,000 investment projects, involving 8.1 billion euros of firm investment, 3.3 billion euros of which as public incentive (including both grants and soft loans).

SI QREN was designed to support projects in mainland Portugal ${ }^{3}$, with the Convergence Objective regions (Norte, Centro and Alentejo) absorbing close to $90 \%$ of the approved fund ${ }^{4}$. The financing and management of SI QREN was carried out by the Competitiveness Factors Operational Program (PO FC) together with the five Regional Operational Programs (OPs). In addition to the OPs, four public agencies (IAMEI, AICEP, TdP and AdI) were involved in the design and implementation of SI QREN (in particular, they were responsible for analysing and evaluating the projects submitted for support, fixing the contracts with the beneficiaries, and monitoring the implementation of supported projects).

The guiding principles and general rules of SI QREN were established by the Decree-Law No. $287 / 2007$ (commonly referred to as "national guidelines") that establishes the main objectives of the policy, namely: increasing the productivity and competitiveness of firms, fostering territorial development, deepening the internationalization of the national economy, increasing business investment, and promoting cooperation among firms and with the science and technology system. These general goals were translated into more detailed objectives in the regulatory documents specific to each support mechanism.

Generally speaking, SI QREN consist of grants and soft loans that help to finance firms' expenditures on productive equipment, $\mathrm{R} \& \mathrm{D}$ activities, and/or the so-called "dynamic competitiveness factors" (these include industrial property, fashion and design, ICT and digital economy, quality management, environment protection and eco-efficiency, innovation consultancy, certification of management systems, marketing, internationalization, social responsibility, safety and health, and gender equality).

\footnotetext{
${ }^{3}$ Specific firm support mechanisms were implemented in the Autonomous Regions of the Azores and Madeira.

${ }^{4}$ Mainland Portugal is composed of five NUTS II regions, which also include Lisboa and Algarve.

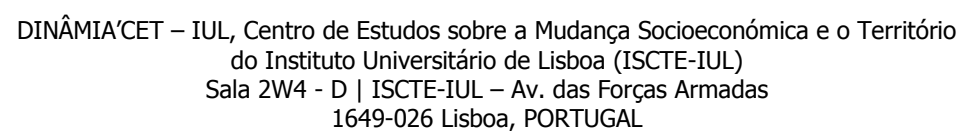


The main support mechanisms under SI QREN targeting single-firms were: SI I\&DT, SI Inovação, SI QPME and the Vouchers. In addition to other regulatory aspects, these mechanisms differ by the type of investment expenditure they predominantly support:

- SI I\&DT is designed to co-finance expenditure related to R\&D activities (including costs with technical staff, patent applications, raw materials and components for pilots or prototypes, technical and scientific assistance, scientific and technical equipment and specific software, etc.);

- SI QPME aims to co-finance SMEs' investments in dynamic competitiveness factors (see description above);

- SI Inovação provides co-financing to firms of all sizes, targeting expenditures related with the acquisition of production machinery and equipment related with innovative investment projects (in addition to the so-called dynamic competitiveness factors);

- The "R\&D vouchers" and "Innovation vouchers" consist in small grants to SMEs for the acquisition of consulting services to support innovation or R\&D activities. A key purpose of the Vouchers is to stimulate the demand for advanced services by SMEs, as well as to encourage the rapprochement between small and medium-sized firms and the entities of the national S\&T system, assuming that this type of relationship and collaboration can constitute a crucial element of strengthening the competitiveness of Portuguese firms.

SI Inovação accounts for almost $3 / 4$ of the incentives given under SI QREN, due to its focus on projects with a strong component of physical investment (which translates into higher average amounts of investment per project), although it only represents $1 / 5$ of the projects and the firms supported. By contrast, SI QPME and the Innovation Vouchers together represent close to $2 / 3$ of beneficiaries and projects, but no more than $15 \%$ of the eligible investment.

Although single-firm projects are largely predominant (both in terms of the number of projects and the amount of public funds involved), SI QREN also aims to support joint initiatives and consortia led by firms, or even projects promoted and/or led by business associations or entities of the scientific and technological system. In these latter cases, a broad range of business and non-business entities can take part in the supported projects.

\footnotetext{
DINÂMIA'CET - IUL, Centro de Estudos sobre a Mudança Socioeconómica e o Território

do Instituto Universitário de Lisboa (ISCTE-IUL)

Sala 2W4 - D | ISCTE-IUL - Av. das Forças Armadas

1649-026 Lisboa, PORTUGAL

Tel. (+351) 210464031 / 210464197 | E-mail: dinamia@iscte-iul.pt | www.dinamiacet.iscte-iul.pt
} 
The support granted by SI QREN takes the form of refundable (soft loans) or non-refundable (grants) subsidies. Non-refundable subsidies generally apply to R\&D projects, expenditures on human resources training within productive investment projects, or incentives of small amounts. In the case of refundable subsidies, the repayment period may vary between five and ten years, involving a period of grace of 2-3 years (varying according to the typology and the nature of the projects). Generally speaking, SI I\&DT, SI QPME and the Vouchers consist of non-refundable grants, while SI Inovação takes the form of soft loans.

The amount of support is defined as a proportion of the total eligible expenses of the project, ranging from $15 \%$ to $75 \%$ depending on the type of investment, the size of the company, the involvement of S\&T entities, among other factors. The incentive ceilings to be allocated in each case are defined by national and EU regulations and are calculated in Gross Grant Equivalent (i.e., the current value of the incentive converted into a non-refundable grant, if applicable).

In sum, SI QREN support mechanisms provide firms with funding on particularly favourable terms, compared to those that typically hold in the credit markets (especially for SMEs). This aspect was decisive throughout much of the implementation of the period under analysis. In fact, from the end of 2008 (following the international financial crisis), and especially after 2010 (i.e., during the euro zone crisis) Portuguese companies faced severe restrictions on access to bank credit, reflected in higher interest rates and guarantees.

\subsection{The theory of change of the policy}

In the present context, the theory of change of the policy corresponds to the description of the goals SI QREN aims to achieve and the causal sequence that runs from the implementation of the policy to the desired changes in the productive fabric. ${ }^{5}$ The theory of change is the basis on which lie some of the most relevant methodological options we made in the context of this project - from the choice of estimation methods and relevant variables, through the selection of the dimensions to consider in the analysis of the heterogeneity of impacts, to the selection of the dimensions to be highlighted in the analysis of results.

\footnotetext{
${ }^{5}$ For literature reviews on the programs' theory of change see, for example, Brousselle \& Champagne (2011), Coryn et al. (2011) or Funnell \& Rogers (2011).

DINÂMIA'CET - IUL, Centro de Estudos sobre a Mudança Socioeconómica e o Território

do Instituto Universitário de Lisboa (ISCTE-IUL)

Sala 2W4 - D | ISCTE-IUL - Av. das Forças Armadas

1649-026 Lisboa, PORTUGAL

Tel. (+351) 210464031 / 210464197 | E-mail: dinamia@iscte-iul.pt | www.dinamiacet.iscte-iul.pt
} 
In an early stage of the project, in order to clarify and deepen of the theory of change, we ran a focus group with 15 experts from both the private sector and the public agencies involved in the implementation of the policy. The focus group resulted in a shared understanding of the core goals of SI QREN, which can be analysed at two levels:

(i) At the aggregate level, SI QREN aims at increasing the weight of knowledge-based and technology intensive activities in the Portuguese economy, and gearing the national production to international markets with a growing demand; more generally, SI QREN aims to increase employment, added value, productivity, and the international competitiveness of the Portuguese economy.

(ii) At the microeconomic level, SI QREN is designed to: strengthen the internal capabilities of SMEs; foster firms' innovation and internationalization activities; promote knowledgebased entrepreneurship; strengthen interactions between actors in the national innovation system; and increase the competitiveness of companies whose strategies are aligned with the aforementioned public policy objectives.

Those goals are pursued through SI QREN by providing enterprises and other beneficiaries with access to finance on more favourable terms than they would otherwise face in the credit markets. In order to ensure that the supported projects contribute to the goals listed above, access to SI QREN is subjected to several selection criteria set out in the various relevant regulatory documents.

The crux of SI QREN's theory of change, describing the sequence of causal processes ranging from policy design to the production of the expected results, is depicted in Figure 1 and will be discussed in more detail below. 
Figure 1 - Chain of expected impacts of SI QREN

\begin{tabular}{|c|c|c|c|c|}
\hline $\begin{array}{l}\text { Design and } \\
\text { implementation of } \\
\text { incentives }\end{array}$ & $\begin{array}{l}\text { Changes in firms' } \\
\text { resources }\end{array}$ & $\begin{array}{l}\text { Desired behavioral } \\
\text { changes }\end{array}$ & $\begin{array}{c}\text { Targeted results at } \\
\text { micro and meso } \\
\text { levels }\end{array}$ & $\begin{array}{l}\text { Targeted results at } \\
\text { the aggregate level }\end{array}$ \\
\hline Eligibility criteria & $\begin{array}{l}\text { Reducing the } \\
\text { cost of financing }\end{array}$ & $\begin{array}{l}\text { Increased } \\
\text { investment in }\end{array}$ & $\begin{array}{l}\text { Increased } \\
\text { competitive }\end{array}$ & $\begin{array}{l}\text { Value added and } \\
\text { employment }\end{array}$ \\
\hline $\begin{array}{l}\text { Projects } \\
\text { evaluation }\end{array}$ & Reducing the & innovation & performance & $\begin{array}{l}\text { growth } \\
\text { aggregates }\end{array}$ \\
\hline & $\begin{array}{l}\text { costs of skilled } \\
\text { staff }\end{array}$ & $\begin{array}{l}\text { Increased } \\
\text { investment in }\end{array}$ & $\begin{array}{l}\text { Strengthening } \\
\text { export }\end{array}$ & Aggregate \\
\hline $\begin{array}{c}\text { Elegible } \\
\text { expenditures }\end{array}$ & & $\begin{array}{l}\text { international- } \\
\text { ization }\end{array}$ & orientation & $\begin{array}{l}\text { productivity } \\
\text { growth }\end{array}$ \\
\hline $\begin{array}{l}\text { Allocation of } \\
\text { funds }\end{array}$ & & More & $\begin{array}{l}\text { Increase of } \\
\text { knowledge }\end{array}$ & National exports \\
\hline $\begin{array}{l}\text { Type and nature } \\
\text { of support }\end{array}$ & needs & activities & Greater weight & \\
\hline $\begin{array}{l}\text { Procedures and } \\
\text { conditionality }\end{array}$ & $\begin{array}{l}\text { Greater financial } \\
\text { autonomy }\end{array}$ & $\begin{array}{l}\text { enterpreneur- } \\
\text { ship }\end{array}$ & $\begin{array}{c}\text { international } \\
\text { activities }\end{array}$ & $\begin{array}{l}\text { Sustained } \\
\text { growth }\end{array}$ \\
\hline
\end{tabular}

SI QREN's regulations establish the eligibility criteria, delimit the expenditures that are eligible for support, specify the criteria for project evaluation, define the projects' targets and deadlines for their realization, as well as the penalties that beneficiaries may incur in case the targets are not met.

One relevant dimension of SI QREN's selectivity concerns the scope of industries that are eligible for support. As a general rule, the SI QREN is directed to investment projects in mining and manufacturing industries, energy production, wholesale and retail trade (SMEs only), tourism (accommodation, catering, car rentals, travel agencies , recreational activities, etc.), road transport and logistics, collection and treatment of solid waste and waste water, information technology services, and technical and business consultancy services. The industries typically excluded (with some specific exceptions) are: agriculture and fisheries (which are supported by separate funds), construction, civil engineering and real estate activities, air and water transport services, postal activities, telecommunication and broadcasting activities, financial services, and collective and personal services.

Although several of those exclusions accrue from EU regulations and do not necessarily reflect national public policy choices, the delimitation of the industry scope of eligible projects reflects a preference for tradable goods or services (or supporting activities). In practice, SI QREN gives a strong emphasis to manufacturing, which represent about $70 \%$ of the amount of support (followed by 
tourism-related activities, 12\%; knowledge-intensive services, 10\%; and wholesale and retail trade, $4 \%)$.

Within each industry, SI QREN favours business projects with certain characteristics. In particular, the analysis of regulatory documents suggests that SI QREN aims to support investment projects in firms with reasonably robust financial and organizational conditions, whose business strategies are based on knowledge, skills, innovation and/or internationalization.

According to the rationale underlying the policy, firms' access to SI QREN is expected to lead them to allocate more resources to innovation, internationalization, networking and entrepreneurship activities, compared to what they would do in the absence of support. One of the crucial assumptions in the design of SI QREN is precisely the notion that support should promote a higher level of private investment that would exist in the absence of the policy (i.e., the additionality effect).

Irrespective of the verification of the additionality effect, it is expected that access to more favourable financing conditions will contribute to improving the performance of the beneficiary firms, resulting in the improvement of indicators such as: value added, employment, productivity, turnover, profitability, financial risk reduction, and firm survival.

The improved performance of the supported companies, in turn, contributes to the desired changes in regional and national economies, both directly and indirectly. The direct impacts of SI QREN are related to the growth of economic activities based on knowledge, innovation and internationalization, resulting from the improved performance of the beneficiary firms. SI QREN is also expected to produce indirect effects insofar as they allow the generation of information, knowledge and competences that benefit the whole of the national productive fabric (and not only the supported firms) in different ways: by providing information on investment opportunities (regarding, e.g., new products and processes, new forms of business organization and inter-business relations, less wellknown niche markets, etc.); by producing technological knowledge that can be used with reduced costs by several firms; by contributing to the formation of skills that may spread throughout the economy through the mobility of workers and managers, or the different forms of interaction and collaboration between economic agents; among others. ${ }^{6}$

\footnotetext{
${ }^{6}$ The different types of positive externalities generated by the supported investments are the fundamental theoretical justification for public support for business investments in R\&D, innovation, internationalization and vocational training. See, for example, Edler \& Fagerberg (2017).
} 
While the theory of change discussed above applies to the SI QREN as a whole, it should be noted that each specific policy mechanism included in the overall policy is targeted to different types of firms, projects and expenditures, differing accordingly in its expected results. Figure 2 classifies the different types of incentive systems according to the characteristics of the direct beneficiaries, the nature of the projects, and their primary objectives.

Figure 2 - Diversity of support mechanisms under SI QREN (with an emphasis on single-firm, competition-based support mechanisms)

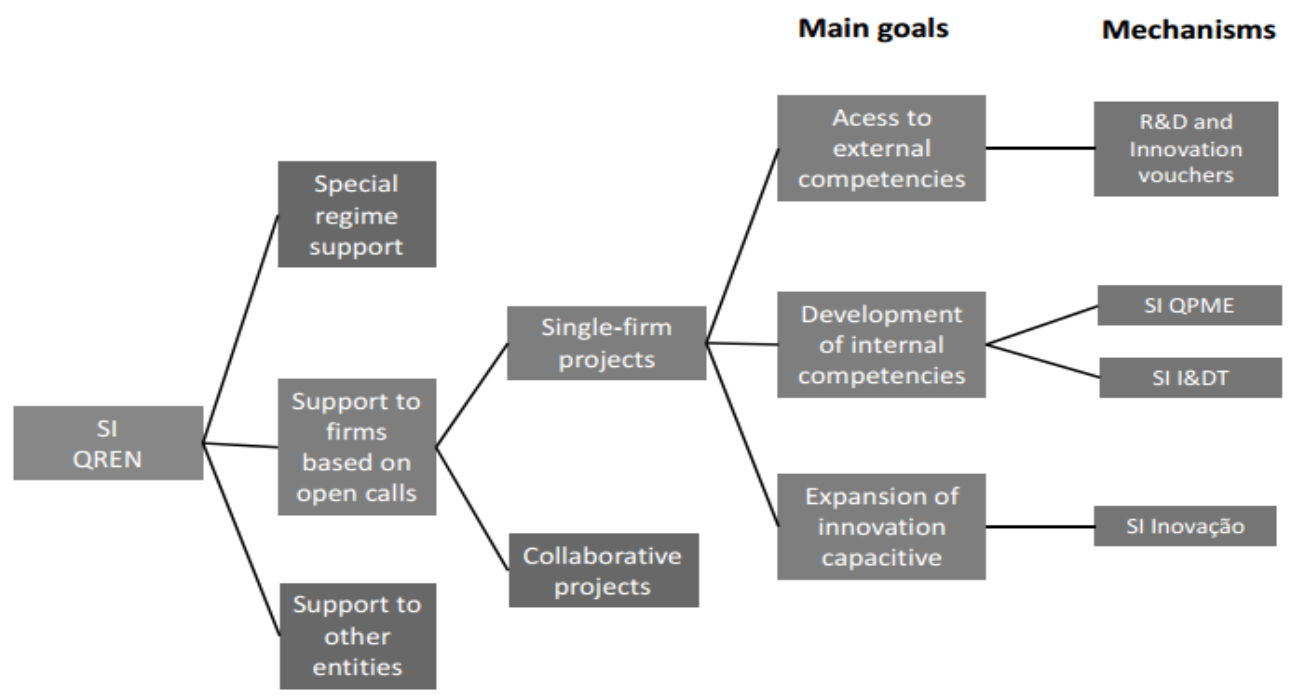

As illustrated in the figure, the policy instruments under SI QREN can be divided among those that subject support to competitive tenders (these are the most common cases, accounting for $90 \%$ of the projects supported and $70 \%$ of the incentive granted) and other instruments (which include large investment projects of a contractual nature).

The policy mechanisms that aim to support single-firm projects submitted to competitive calls, which constitute the focus of our research, can be divided into three major subgroups:

(i) Single-firm projects that aim to access external skills: the Vouchers. These are small grants (up to 25 thousand euros) to projects selected through a simplified process, which pursue two main objectives: to facilitate firms' access to external sources of technology and management skills; and stimulate the demand for this type of services by smaller firms.

(ii) Single-firm projects aimed at enhancing the internal capabilities of firms. This include SI QPME (which aims to stimulate the activities of companies to strengthen dimensions such as internationalization, marketing, design, industrial property, information technology, certification of management systems, energy efficiency, and other dynamic factors of competitiveness,

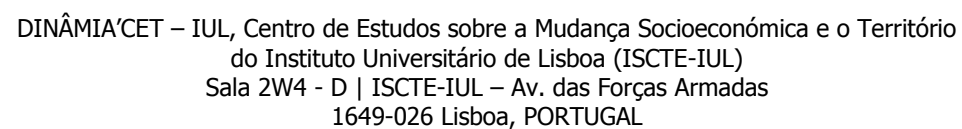


involving a modest component of investments in machinery and equipment) and single-firm SI I\&DT projects (aimed at $R \& D$ projects and $R \& D$ units within firms, typically involving a major component of tangible investments).

(iii) Single-firm projects that aim to expand the innovative productive capacity of firms: SI Inovação. This includes projects of productive innovation and knowledge-based entrepreneurship, which distinguish themselves by their strong component of investment in tangible assets dedicated to productive and operational activities.

In addition to the support mechanisms targeting single-firm projects to be selected through open calls, there are three other mechanisms under SI QREN, namely:

(iv) Special regime projects. These consist in a limited number of large projects (48 projects with a minimum investment of 5 million euros) where public support is directly negotiated between the national authorities and the beneficiaries, and which are justified by the knock-on effects on the national economy.

(v) Collaborative $R \& D$ projects. It includes $R \& D$ projects involving various participants, aiming to promote the creation and consolidation of networks of collaboration between companies, and between them and other entities of the scientific and technological system, as part of the technological research activities and experimental development. Although the collaborative logic is the distinctive aspect of these measures, the projects in question sometimes involve large investments in the scientific and technological capacity and skills of the companies involved.

(vi) Collective projects. These are typically conducted by business associations to support firms' internationalization and innovation, with the aim of promoting synergies and generating externalities that benefit a wide range of companies.

The above discussion allows us to associate each type of micro-level objectives identified for the SI QREN as a whole to each specific support mechanism. This is shown in Table 1.

Table 1 - Relationship between support mechanisms and the microeconomic goals of SI QREN

\begin{tabular}{|l|c|c|c|c|c|}
\cline { 2 - 6 } \multicolumn{1}{c|}{} & $\begin{array}{c}\text { Strengthening } \\
\text { the internal } \\
\text { competences of } \\
\text { SMEs }\end{array}$ & $\begin{array}{c}\text { Increase } \\
\text { investment in } \\
\text { innovation and } \\
\text { internacio- } \\
\text { nalization }\end{array}$ & $\begin{array}{c}\text { Increase } \\
\text { qualified } \\
\text { entrepreneur- } \\
\text { ship }\end{array}$ & $\begin{array}{c}\text { Reinforcing } \\
\text { interactions } \\
\text { among NIS } \\
\text { actors }\end{array}$ & $\begin{array}{c}\text { Increase the } \\
\text { competitive } \\
\text { performance of } \\
\text { companies }\end{array}$ \\
\hline Innovation and R\&D vouchers & + & + & & ++ & + \\
\hline Single-firm SI I\&DT projects & +++ & ++ & & +++ & ++ \\
\hline Single-firm SI QPME projects & +++ & +++ & + & + & ++ \\
\hline Single-firm SI Inovação projects & ++ & +++ & & ++ & +++ \\
\hline Special regime projects & & +++ & & ++ & + \\
\hline Collaborative Projects & ++ & ++ & & +++ & + \\
\hline Collective projects & ++ & ++ & + & ++ & + \\
\hline
\end{tabular}

Note: The number of "+" signs in each cell ranges from one to three and is proportional to the intensity of the relationship between objectives and support mechanisms.

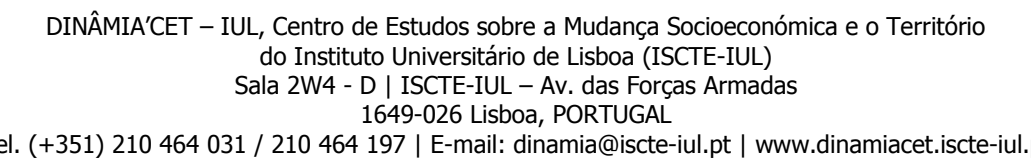


The relations between each support mechanism under SI QREN and each microeconomic policy goal, as displayed in the table, resulted from the aforementioned focus group and take into account the relative weight of public support with regard to firms' assets, which tends to vary greatly between mechanisms. For example, the weight of support tends to be very modest in the case of Vouchers and very high in the case of qualified SI Inovação (as can be seen in Table 2, which shows the median value of the ratio between the amount of support and the total assets of the companies for different support mechanisms). This means that the expected impact of incentives on the overall performance of firms tends to vary significantly also because of the relative importance of support for the company in question.

Table 2 - Ratio of total support to total firms' assets, by support mechanism

\begin{tabular}{|l|c|}
\cline { 2 - 2 } \multicolumn{1}{c|}{} & Median \\
\hline Vouchers & $5 \%$ \\
\hline Single-firm SI QPME projects & $6 \%$ \\
\hline Single-firm SI I\&DT projects & $20 \%$ \\
\hline Single-firm SI Inovação projects & $29 \%$ \\
\hline
\end{tabular}

Source: QREN monitoring system, own treatment

Lastly, it should be noted that the support mechanisms under SI QREN also differ with regard to the expected duration of the investment projects. As can be seen in Table 3, projects supported through Vouchers or SI I\&DT are typically completed in less than one year, while other supported projects often take three years or more to complete. Differences in the duration of the projects also imply differing expectations as to the time horizon for the effects of public support on firms' performance to be observable.

Table 3 - Duration of the investment period by type, in years

\begin{tabular}{|l|c|c|}
\cline { 2 - 3 } \multicolumn{1}{c|}{} & Average & Percentile 75 \\
\hline Vouchers & 1.2 & 1.0 \\
\hline Single-firm R\&D projects & 1.4 & 1.0 \\
\hline Single-firm SI Inovação projects & 3.3 & 4.0 \\
\hline Single-firm SI QPME projects & 3.6 & 4.0 \\
\hline
\end{tabular}

Source: QREN monitoring system, own treatment

DINÂMIA'CET - IUL, Centro de Estudos sobre a Mudança Socioeconómica e o Território do Instituto Universitário de Lisboa (ISCTE-IUL)

Sala 2W4 - D | ISCTE-IUL - Av. das Forças Armadas 1649-026 Lisboa, PORTUGAL

Tel. (+351) 210464031 / 210464197 | E-mail: dinamia@iscte-iul.pt | www.dinamiacet.iscte-iul.pt 
The impact of EU-funded direct subsidies on several dimensions of firm performance in Portugal:

The specificities of each support mechanism under SI QREN should be taken into account not only in the methodological options, but above all in the interpretation of results.

DINÂMIA'CET - IUL, Centro de Estudos sobre a Mudança Socioeconómica e o Território do Instituto Universitário de Lisboa (ISCTE-IUL)

Sala 2W4 - D | ISCTE-IUL - Av. das Forças Armadas

1649-026 Lisboa, PORTUGAL

Tel. (+351) 210464031 / 210464197 | E-mail: dinamia@iscte-iul.pt | www.dinamiacet.iscte-iul.pt 


\section{DATA AND DESCRIPTIVE STATISTICS}

This research was based on a unique set of firm-level data sources, put together specifically for this purpose. The original data sources are the following (the entities providing the information are indicated in brackets):

- Integrated System of Enterprise Accounts (National Statistics Institute - INE)

- Quadros de Pessoal (Ministry of Labour, GEPE)

- SI QREN policy data (Managing Authority coordinating SI QREN, Compete 2020)

- External markets statistics (INE)

- Data on Industrial Property use in Portugal (National Institute of Industrial Property)

- National Scientific and Technological Potential Survey (Ministry of Science, DGEEC)

- Listing of companies certified as SMEs (Agency for SME Support - IAPMEI)

- List of companies with the Statutes of "SME Leader" and "SME Excellence" (IAPMEI) ${ }^{7}$

- List of firms with certified management systems (Portuguese Institute for Accreditation) ${ }^{8}$

- Data on firm support during the EU Policy programming period 2000-2006 (COMPETE 2020)

- List of companies that have access to credit lines (PME Investimentos - Investment Society)

The different datasets were merged by means of a unique identification code, resulting from a biunivocal transformation of firms' tax identification number ${ }^{9}$. The consolidated database thus obtained included around 5 million observations and more than 300 variables, dating from 2004 to 2015 . This allowed for a detailed characterization of firms in many different dimensions (size, location, industry, financial situation and performance, innovation and R\&D activities, human capital, intellectual property, exports, access to different forms of public support to firms, eco-efficiency, intra-firm wage distribution and wage levels, gender equality, etc.).

The data were cleaned according to several exclusion criteria. The retained observations were subjected to specific treatment, in order to fill in missing data whenever possible. After the quality

\footnotetext{
${ }^{7}$ Every year, IAPMEI (a public agency dedicated to SME support policies), together with institutional partners from the banking sector, certifies firms as PME Leader and PME Excellency labels on the basis of their recent financial performance. These labels are widely used by certified firms as part of their marketing strategy, and typically allowed then to access external financing at more favourable conditions.

8 These include certifications like ISO 9001.

9 The transformation of firms' ID was performed by the National Statistics Institute in order to ensure the principle of statistical confidentiality.
} 
treatment of the data, 6,054 treated firms remained available for analysis, which corresponds to about $92 \%$ of SI QREN's beneficiaries. ${ }^{10}$

The retained observations were then subjected to descriptive analysis, leading to the identification of relevant ex-ante differences between treated and non-treated firms. More specifically, the available data show that SI QREN was biased towards: manufacturing industries and knowledge-based services firms, firms with 10 or more workers (and in particular fifty or more), and more sophisticated and financially robust firms.

Table 4 presents a set of comparative data on treated and non-treated firms, considered in the year before the beginning of the supported projects. ${ }^{11}$

Table 4 - Ex ante comparison between treated and non-treated firms

\begin{tabular}{|l|r|r|}
\hline & Treated firms & Non-treated firms \\
\hline Average value added & $2,739,467 €$ & $263,348 €$ \\
\hline Average turnover & $12,017,437 €$ & $1,186,701 €$ \\
\hline Average net profit & $485,017 €$ & $35,564 €$ \\
\hline Average productivity & $38,101 €$ & $19,208 €$ \\
\hline Average wage & $894 €$ & $591 €$ \\
\hline Average $n$. of employees & 61.3 & 10.1 \\
\hline Average $n$. of university degree holders & 9.9 & 1.2 \\
\hline \% of firms performing R\&D & $24 \%$ & $1 \%$ \\
\hline \% of firms with financial autonomy $>0.2$ & $84 \%$ & $65 \%$ \\
\hline$\%$ of firms with EBIT $>0$ & $70 \%$ & $50 \%$ \\
\hline$\%$ of employees on the minimum wage & $8 \%$ & $15 \%$ \\
\hline \% of firms benefiting from credit lines & $76 \%$ & $32 \%$ \\
\hline \% of firms previous EU Cohesion support & $13 \%$ & $0 \%$ \\
\hline
\end{tabular}

Sources: SCIE (INE) and QP (MTSSS)

Table 4 allows us to appreciate the substantial differences between treated and non-treated firms according to several characteristics: turnover, staff employed, exports, productivity, workers' education levels, financial situation, etc.

The ex ante differences between treated and non-treated firms consistently reflect the regulatory framework of SI QREN, as well as the detailed eligibility and selection criteria used in each call for

\footnotetext{
10 The number of observations actually used in the estimation of impacts is lower due to lack of data for specific years or the impossibility of finding sufficiently similar non-treated firms.

${ }_{11}$ The figures presented in the table correspond to the means of the variables for the two company samples, after a preliminary treatment of the data was applied in order to exclude unsupported companies that could hardly ever have been supported given their combination (more on this below). If we considered the two groups of companies without any previous treatment of the data, the differences would be even more pronounced.
} 
applications, as discussed in the previous section. They also reflect the fact that companies with different characteristics have different propensities to apply for SI QREN. A number of factors can determine this process of self-selection: expectations of success in obtaining support, pro-activity of management teams (or consulting firms specialised in applying for public support), firms' position in their growth cycle, among others.

Such ex-ante differences between treated and non-treated firms are a key challenge for the rigorous measurement of policy impacts, and justify the methodological options described in the following section. 


\section{METHODS}

In this study we combine the use of matching methods with the bias correction procedure put forward by Abadie and Imbens (2002, 2011), in order to estimate the impact of SI QREN on firms' performance.

Our aim is to estimate the feasible average treatment effect on the treated (FATT). The estimate is "feasible" because the estimates only apply to the sub-sample of treated units for which it was possible to conceive a reasonable control, assuring the internal validity of results; no extrapolation is made nor pretended. The criteria established was to achieve a consistent and as efficient as possible estimation (with priority given to consistency), and maintain a large sample size to bring the support of asymptotic knowledge of the estimator to analysis robustness. The targeted biases to address were selection, functional form, and omitted variables biases.

The estimation process was made in three steps: pre-processing the data; matching treated and nontreated firms; and correcting the remaining bias. In the following sections we present the matching methods, briefly describe the aforementioned bias correction procedure, and discuss some relevant details of the experimental design.

\subsection{Data pre-processing and matching methods}

We started by pre-processing the data through Coarsened Exact Matching (CEM; see Iacus et al., 2012), as suggested in Blackwell et al. (2009), imposing coarsened multivariate balance, reinforcing the overlap assumption, and possibly improving the further parametric steps of the estimation (Ho et al., 2007), as well as reducing rare event problems related to the estimation of the propensity score. This step imposes exact matching on the first level of NACE rev.2 industry classification, and on main categories of the following variables: number of employees (four groups), turnover (four groups), financial autonomy (three groups), productivity (two groups - below or above the average of the corresponding 3 digit-level industry), and number of employees with a university degree (idem).

The second step consisted in matching treated and control units. We tested several alternatives matching methods in the course of the project. We report here the results obtained through Mahalanobis Distance Matching (MDM) - which was the one leading to the most similar treated and 
control groups - as well as the commonly used Propensity Score Matching (PSM), for robustness purposes.

Since we assume that treatment is only unconfounded conditioning on more than two continuous variables and that usual matching estimators are biased when more than one continuous covariate is used (Abadie and Imbens, 2006), we rely on the bias correction proposed by Abadie and Imbens $(2002,2011)$. Thus, the third and last step is the application of the already presented estimator to the treated units, and their respective matched subset, that resulted from the second step, as explained in the following subsection.

\subsection{The bias corrected matching estimator}

The baseline model under use builds upon Rubin's potential outcome framework (Rubin, 1974) where, for $\mathrm{N}$ units of index $i$ ranging from 1 to $N, W_{i}$ is a binary variable describing the treatment assignment (assuming 1 for treated and 0 otherwise). The potential outcomes $Y_{i}(1)$, for the event of treatment, and $Y_{i}(0)$ otherwise, are realized and observed depending on treatment assignment $\mathrm{W}_{\mathrm{i}}$ as

$$
Y_{i}= \begin{cases}Y_{i}(0) & \text { se } W_{i}=0 \\ Y_{i}(1) & \text { se } W_{i}=1\end{cases}
$$

The quantity of interest of the model is the average treatment effect on the treated

$$
\tau_{\text {treated }}=E\left[Y_{i}(1)-Y_{i}(0) \mid W_{i}=1\right]
$$

Following Abadie and Imbens (2011), the bias corrected matching estimator $\hat{\tau}_{\text {treated }}^{b c m}$ is defined as

$$
\hat{\tau}_{\text {treated }}^{\text {bcm }}=\frac{1}{N_{\text {treated }}} \sum_{W_{i}=1}\left(Y_{i}-\hat{Y}_{i}(0)\right)
$$

Being $J_{M}(i)$ the matched sample of $i$ with size $M_{i}$ and $\hat{\mu}_{0}$ an unbiased estimate of $E\left[Y_{i}(0) \mid X_{i}=x\right]$, for every $i \in N_{\text {treated }}$ and for every $j \in J_{M}(i)$, the estimator $\widehat{Y}_{i}(0)$ is given by

$$
\widehat{Y}_{i}(0)=\frac{1}{M_{i}} \sum_{j \in J_{M}(i)}^{M_{i}}\left(\mathrm{Y}_{j}+\widehat{\mu}_{0}\left(\mathrm{X}_{i}\right)-\widehat{\mu}_{0}\left(X_{j}\right)\right)
$$

defining an $N^{1 / 2}$ consistent estimator of $\tau_{\text {treated }}$ under given assumptions (see Abadie and Imbens, 2011).

The variables $\mu_{0}\left(\mathrm{X}_{i}\right)$ and $\mathrm{e}=\operatorname{Pr}(\mathrm{W}=1 \mid \mathrm{X}=\mathrm{x})$ are approximated as a linear combination of $\mathrm{X}$, being the estimate $\hat{e}$ the maximum likelihood estimate of a logistical model of $e$, whereas the estimate 
$\hat{\mu}_{0}\left(\mathrm{X}_{i}\right)$ is a linear least squares estimate of the model of $\mu_{0}\left(\mathrm{X}_{i}\right)$ and is estimated only on the subsample of matched controls.

Given the illustration made by Ho et al. (2007) it is expected that the linear approximation done after matching will be adequate. Moreover, the bias of this estimate brings little noise to the estimation of the quantity of interest (Abadie and Imbens, 2011) while allowing multiple continuous covariates and a large N.

Heteroskedasticity robust variances were estimated following Abadie et al. (2004) resorting also to a matching procedure between treated units.

\subsection{Output and control variables}

In order to analyse the impact of SI QREN on firms' performance we consider 50 output variables, organized around the following 11 dimensions:

- Investment

- Financial situation

- Human capital

- Innovation

- Internationalization

- Firm growth

- Competitiveness

- Eco-efficiency

- Job quality

- Intra-firm income distribution

- Gender equality

The corresponding output variables are listed in Table A.1 in annex.

\subsection{Control variables}

Taking $t$ as the time reference year in which the first expenditures related with the supported project were made by the treated firm, the observable covariates, $x \in X$, are:

- Number of employees (in logs)

- Turnover (logs)

- Total exports (in logs)

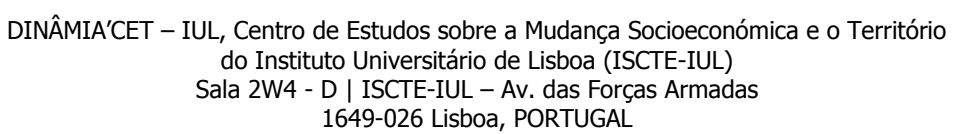


- Performance of R\&D activities (dummy)

- Gross Fixed Capital Formation (average of the last three years, in logs)

- Firm age (in logs)

- Number of workers with higher education (in logs)

- Weight of non-EU exports on turnover

- Purchasing power of the corresponding NUTS III region in 2007

- Labour productivity (dummy)

- Return on turnover

- Had access to some credit line during the period (dummy)

- Firm supported under the previous cycle of EU Cohesion funds (dummy)

- Absolute variation in the number of employees

- Financial autonomy $>20 \%$ (dummy)

- Had a positive EBIT in the last three years (dummy)

This set of variables was selected in view of its potential influence on firm performance as well as on the propensity of firms to get support from SI QREN. The last two variables, regarding financial autonomy and EBIT constitute eligibility conditions of the policy.

In addition to these, we also included as control variables the pre-treatment value (at t-1) and the pretreatment trend (between $\mathrm{t}-2$ and $\mathrm{t}-1$ ) of the output variable (where $t$ corresponds to the first year of the supported project). By including the pre-treatment trend of the output variable as covariate we are not only controlling for the growth trajectory of the firm (which may influence its post-treatment performance).

The estimations were run year by year, in order to control for the business cycle and other common exogenous factors. The yearly results were later aggregated, obtaining the corresponding impacts through a weighted average of the impacts estimated for each year (using the number of treated firms per year as weights). Statistical tests on aggregate estimators are based on an adjusted weighted average of the variances of estimated parameters for each year. 


\subsection{Balancing metrics}

The balancing property of samples of treated and non-treated firms that resulted from the matching procedures was assessed on the basis of two metrics: the standardized difference in means and the variance ratio. We consider that the statistical distributions of two matched samples are sufficiently similar when the standardized difference in means is equal to or less than 0.25 (in absolute terms) and the variance ratio does not differ from 1 by more than 0.25 (in absolute terms). Otherwise, we assume that the overlapping condition does not hold, and therefore that the estimated average differences in performance between treated and non-treated firms cannot be attributed to the policy under analysis.

DINÂMIA'CET - IUL, Centro de Estudos sobre a Mudança Socioeconómica e o Território do Instituto Universitário de Lisboa (ISCTE-IUL)

Sala 2W4 - D | ISCTE-IUL - Av. das Forças Armadas

1649-026 Lisboa, PORTUGAL

Tel. (+351) 210464031 / 210464197 | E-mail: dinamia@iscte-iul.pt | www.dinamiacet.iscte-iul.pt 


\section{RESULTS}

We estimated the impacts of the policy under analysis both for the SI QREN as a whole and for each of the specific support mechanisms targeting single-firm projects, namely: SI Inovação, SI QPME, SI I\&DT, Vouchers, and Multi-typology projects (i.e., situations in which the same company obtained support from different mechanisms). Due to the reduced number of treated firms and the difficulties in obtaining samples with adequate balancing properties, we dropped the cases of SI I\&DT and Multitypology from the analysis. Thus, we only report here the results for SI Inovação, SI QPME and the Vouchers.

In what follows we start by presenting the main results of the SI QREN as a whole, and then report the results by support mechanism.

\subsection{Global impacts}

Table 5 presents the estimated impacts that are statically significant and robust to both matching methods - PSM and MDM.

Table 5 - Positive, statistically significant and robust impacts of SI QREN as a whole

\begin{tabular}{|c|c|c|}
\hline Output variable & PSM & MDM \\
\hline Gross Value Added & $352,821 € * * *$ & $376,114 € * * *$ \\
\hline Net profit & $281,545 € * *$ & $452,396 € * * *$ \\
\hline Market share of turnover & 0.01 p.p. ${ }^{* * *}$ & 0.02 p.p. ${ }^{* * *}$ \\
\hline Exports to the EU & $355,321 € *$ & $431,198 € * * *$ \\
\hline Geographic diversification of exports & 2.1 p.p. $* * *$ & 2.3 p.p. $* * *$ \\
\hline Export Intensity & $0.04 * * *$ & $0.04 * * *$ \\
\hline Expenditures in R\&D & $23,219 € * * *$ & $38,727 € * * *$ \\
\hline Probability of patent application & 2 p.p. $* * *$ & 2 p.p. $* * *$ \\
\hline Probability of trademark application & 12 p.p. $* * *$ & 11 p.p. $* * *$ \\
\hline Probability of design application & 1 p.p. $* * *$ & 1 p.p. $* * *$ \\
\hline Probability of other IP application & 3 p.p. $* * *$ & 2 p.p. $* * *$ \\
\hline Probability of obtaining new certification & 7 p.p. $* * *$ & 6 p.p. $* * *$ \\
\hline N. of employees with a university degree & $1.3^{* * *}$ & $1.6^{* * *}$ \\
\hline N. of qualified employees & $3.4 * *$ & $4.4^{* * *}$ \\
\hline
\end{tabular}

Note: The asterisks correspond to the $p$-value of each estimate $(* * *<0.01 ; * *<0.05 ; *<0.1)$.

DINÂMIA'CET - IUL, Centro de Estudos sobre a Mudança Socioeconómica e o Território do Instituto Universitário de Lisboa (ISCTE-IUL)

Sala 2W4 - D | ISCTE-IUL - Av. das Forças Armadas

1649-026 Lisboa, PORTUGAL

Tel. (+351) 210464031 / 210464197 | E-mail: dinamia@iscte-iul.pt | www.dinamiacet.iscte-iul.pt 
The results in table 5 suggest that SI QREN had a positive and statistically significant impact on firm performance after three years in several domains that constitute explicit goals of the policy (as evidenced in the previous discussion on the theory of change). These include: innovation (R\&D expenditures and IP use), internationalization (exports to the EU, export intensity, and geographical diversification of exports), human capital (number of employees with a university degree and number of qualified workers), firm size (in gross value added), and market share in turnover.

For other variables, shown in Table 6, we obtained positive and statistically significant impacts for several other variables only when using our preferred estimation method (MDM). This applies to the number of employees, total exports, several R\&D-related variables, and wage-related variables.

Table 6 - Positive, statistically significant but less robust impacts of SI QREN as a whole

\begin{tabular}{|l|c|c|}
\hline Output variable & PSM & MDM \\
\hline N. of employees & 3.0 & $1.6^{* * * *}$ \\
\hline N. of employees with a scientific/technological background & 0.3 & $0.4^{* * *}$ \\
\hline N. of R\&D staff & 0.0 & $0.03^{* * *}$ \\
\hline R\&D intensity on value added & 0.03 & $578,596 €^{* * *}$ \\
\hline Total exports & $536,324 €$ & $422,806 €^{* * *}$ \\
\hline Exports to outside the EU & $218,226 €$ & $420 €^{* * *}$ \\
\hline Total wage costs & $193 €$ & $10 €^{*}$ \\
\hline Average wages & $6 €$ & \\
\hline
\end{tabular}

We did not find any statistically significant result in the case of variables related with the financial situation of the firm (e.g., costs of financing, financial autonomy, general liquidity), profit ratios (e.g. Return on Assets, Net Return on Equity), eco-efficiency (intensity of use of water, fuel and electricity), nor gender equality (e.g., gender wage gap, number of women in top management).

A particular, but very relevant case is worth mentioning: that of Gross Fixed Capital Formation (GFCF). The estimation of impacts for this variable using each of the matching methods gives rise to opposite global conclusions (both being statistically significant): using PSM the impact is negative, whereas using MDM the impact is positive. This discrepancy stems from the fact that each method gives rise to very different control groups, the number of untreated firms included in the sample - and the variance of estimated impacts - being much higher in the case of PSM. The differences between 
the impacts estimated by the two methods practically disappear when the analysis is limited to companies with less than 250 workers, indicating that the negative global impacts obtained by the PSM are due to the presence of abnormally large companies in the control group that have in very peculiar trajectories of fixed capital investment. Moreover, the results are robust for both methods when we focus on specific support mechanisms (instead of the SI QREN as a whole), as is done in the following subsection.

\subsection{Impacts by support mechanism}

As discussed in Section 2, the different support mechanisms under SI QREN vary according to the specific objectives they pursue, the nature of the projects they support, the type of expenditures considered as eligible, and the amounts of public support involved.

For example, given its focus on firms' investment in productive capacity, SI Inovação is associated with higher average volumes of investment and also higher levels of public support: in the samples that were used to produce the results presented below, the average incentive was around 1.2 million euros for SI Inovação, 100,000 euros for SI QPME, 23,000 euros for the Vouchers, and 671,000 euros for the SI QREN as a whole.

The support mechanisms under SI QREN also differ in the average size of the beneficiary firms: the average turnover of the companies supported is around 2.2 million euros for SI Inovação, 1.6 million euros for SI QPME, and one million euros for the Vouchers. The corresponding figures for the average number of employees per firm are 30.1, 19.2 and 16.5, respectively.

It is therefore expected that the impact of the policy varies across support mechanisms. The impact is expected to be more pronounced for SI Inovação and less relevant for the Vouchers in all variables that are measured as absolute pre- and post-treatment differences (e.g. variables in which the impact is measured as variation in euros or number of employees). The results presented in Table 7 confirm this expectation. $^{12}$

\footnotetext{
${ }^{12}$ For simplicity, only the results obtained based on the method we take as reference (MDM) are presented.

DINÂMIA'CET - IUL, Centro de Estudos sobre a Mudança Socioeconómica e o Território

do Instituto Universitário de Lisboa (ISCTE-IUL)

Sala 2W4 - D | ISCTE-IUL - Av. das Forças Armadas

1649-026 Lisboa, PORTUGAL

Tel. (+351) 210464031 / 210464197 | E-mail: dinamia@iscte-iul.pt | www.dinamiacet.iscte-iul.pt
} 
Table 7 - Main results by support mechanism

\begin{tabular}{|c|c|c|c|c|}
\hline & SI QREN & SI Inovação & SI QPME & Vouchers \\
\hline Gross fixed capital formation & $317,781 € * * *$ & $601,446 € * * *$ & $54,529 € * * *$ & $20,675 €$ \\
\hline Gross value added & $376,114 € * * *$ & $495,241 € * * *$ & $160,744 € * * *$ & $17,327 €$ \\
\hline Turnover & $838,994 €$ & $3,381,480 € * * *$ & $559,472 € * * *$ & $93,997 €$ \\
\hline Net profit & $452,396 € * * *$ & $633,225 € * * *$ & $53,325 € * * *$ & $19,544 €$ \\
\hline Exports & $578,596 € * * *$ & $2,389,531 € * * *$ & $326,282 € * * *$ & $35,640 €$ \\
\hline$R \& D$ expenditures & $38,727 € * * *$ & $45,094 € * * *$ & $127 €$ & $-172 €$ \\
\hline No. Of employees & $8.23 * * *$ & $13.54 * * *$ & $3.70 * * *$ & $1.43 * *$ \\
\hline No. of workers with a university degree & $1.6^{* * *}$ & $1.8 * * *$ & $0.9 * * *$ & $0.2 * *$ \\
\hline Science and technology staff & $1.6^{* * *}$ & $0.9 * *$ & $1.2 * * *$ & $0.2 * *$ \\
\hline No. of skilled workers & $4.4^{* * *}$ & $7.5^{* * *}$ & $2.1 * * *$ & $0.8 *$ \\
\hline No. of employees with a permanent contract & $3.3 * * *$ & 2.4 & $1.5^{* * *}$ & $0.9 *$ \\
\hline Financial autonomy & 0.03 & -0.04 & $0.03 * *$ & 0.03 \\
\hline General Liquidity & -0.48 & -0.65 & $-1.28 * *$ & 0.10 \\
\hline Export Intensity & $0.04 * * *$ & $0.03 * * *$ & $0.06 * * *$ & 0.00 \\
\hline Market share of turnover & 0.02 p.p. ${ }^{* * *}$ & 0.04 p.p. $* * *$ & 0.00 p.p. & 0.00 p.p. \\
\hline Geographical diversification of exports & 2 p.p. $* * *$ & 2 p.p. $* *$ & 3 p.p. $* * *$ & 0 p.p. \\
\hline Probability of patent application & 2 p.p. $* * *$ & 1 p.p. & & \\
\hline Probability of trademark application & 11 p.p. ${ }^{* * *}$ & 7 p.p. $* * *$ & 15 p.p. ${ }^{* * *}$ & 3 p.p. $*$ \\
\hline Probability of obtaining a new certification & 6 p.p. $* * *$ & 7 p.p. $* * *$ & 7 p.p. $* * *$ & 3 p.p. $* * *$ \\
\hline Incidence of temporary employment & 4 p.p. $* * *$ & 7 p.p. $* * *$ & 5 p.p. $* * *$ & Op.p. \\
\hline Intensity of fuel use & -0.01 & $-0.01 * *$ & -0.01 & -0.02 \\
\hline Gender pay gap & $9.5 €$ & $34.5 € * *$ & $4.1 €$ & $39.4 € * *$ \\
\hline
\end{tabular}

Note: The results presented in the table were produced using the MDM method. The asterisks correspond to the $p$-value of each estimate $(* * *<0.01 ; * *<0.05 ; *<0.1)$.

As shown in table 7, SI Inovação produces stronger impacts than the SI QREN's average and SI QPME in variables such as GFCF, turnover, GVA, market share, net profit, exports, number of employees, and skilled staff.

To a certain extent, the stronger impacts of SI Inovação as compared to the other support schemes stem from the fact that it tends to support larger firms. In order to control for this size effect, we present in Table 8 the results in terms of both the absolute and the relative impacts of the policy (with the latter being computed as the ratio of former to the pre-treatment value of the outcome variable).

DINÂMIA'CET - IUL, Centro de Estudos sobre a Mudança Socioeconómica e o Território

do Instituto Universitário de Lisboa (ISCTE-IUL)

Sala 2W4 - D | ISCTE-IUL - Av. das Forças Armadas

1649-026 Lisboa, PORTUGAL

Tel. (+351) 210464031 / 210464197 | E-mail: dinamia@iscte-iul.pt | www.dinamiacet.iscte-iul.pt 
Table 8 - Estimated impacts in absolute and relative terms for a selection of outcome variables

\begin{tabular}{|c|c|c|c|c|}
\hline & & SI QREN & SI Inovação & SI QPME \\
\hline \multirow{3}{*}{$\begin{array}{l}\text { Gross value } \\
\text { added }\end{array}$} & Average value at $\mathrm{t}-1$ & $2,738,647 €$ & $3,140,324 €$ & $887,855 €$ \\
\hline & Absolute change between $t-1$ and $t+2$ & $376,114 €$ & $495,241 €$ & $160,744 €$ \\
\hline & Relative change between $\mathrm{t}-1$ and $\mathrm{t}+2$ & $14 \%$ & $16 \%$ & $18 \%$ \\
\hline \multirow{3}{*}{ Turnover } & Average value at $\mathrm{t}-1$ & $12,017,437 €$ & $11,875,255 €$ & $3,669,966 €$ \\
\hline & Absolute change between $t-1$ and $t+2$ & $838,994 €$ & $3,381,480 €$ & $559,472 €$ \\
\hline & Relative change between $t-1$ and $t+2$ & $7 \%$ & $28 \%$ & $15 \%$ \\
\hline \multirow{3}{*}{ Exports } & Average value at $\mathrm{t}-1$ & $4,497,836 €$ & $6,479,229 €$ & $1,174,107 €$ \\
\hline & Absolute change between $t-1$ and $t+2$ & $578,596 €$ & $2,389,531 €$ & $326,282 €$ \\
\hline & Relative change between $t-1$ and $t+2$ & $13 \%$ & $37 \%$ & $28 \%$ \\
\hline \multirow{3}{*}{$\begin{array}{l}\text { No. of } \\
\text { employees }\end{array}$} & Average value at t-1 & 61.3 & 84.8 & 31.9 \\
\hline & Absolute change between $\mathrm{t}-1$ and $\mathrm{t}+2$ & 8.2 & 13.5 & 3.7 \\
\hline & Relative change between $\mathrm{t}-1$ and $\mathrm{t}+2$ & $13 \%$ & $16 \%$ & $12 \%$ \\
\hline \multirow{3}{*}{$\begin{array}{l}\text { No. of } \\
\text { employees with } \\
\text { a university } \\
\text { degree }\end{array}$} & Average value at $\mathrm{t}-1$ & 9.9 & 8.4 & 5.2 \\
\hline & Absolute change between $\mathrm{t}-1$ and $\mathrm{t}+2$ & 1.6 & 1.8 & 0.9 \\
\hline & Relative change between $\mathrm{t}-1$ and $\mathrm{t}+2$ & $17 \%$ & $21 \%$ & $18 \%$ \\
\hline
\end{tabular}

Note: The results presented I the table were produced using the MDM method. The asterisks correspond to the p-value of each estimate $(* * *<0.01 ; * *<0.05 ; *<0.1)$.

As can be seen, in the case of gross value added the impact measured in relative terms is slightly larger for SI QPME than for SI Inovação, contrary to what was reported in the analysis of impacts in absolute terms. However, the same does not happen with the remaining variables considered here, for which SI Inovação produces stronger impacts (in spite of the fact that treated firms have larger pretreatment values of the outcome variables).

In those cases in which the pre-treatment value of the outcome variables is insufficient to explain the differences in impacts between support mechanisms, these differences tend to be linked to the specificities of each policy instrument, namely:

- The average amounts of support, which are higher for SI Inovação and smaller in the case of Vouchers, with SI QPME as an intermediate case.

DINÂMIA'CET - IUL, Centro de Estudos sobre a Mudança Socioeconómica e o Território

do Instituto Universitário de Lisboa (ISCTE-IUL)

Sala 2W4 - D | ISCTE-IUL - Av. das Forças Armadas

1649-026 Lisboa, PORTUGAL

Tel. (+351) 210464031 / 210464197 | E-mail: dinamia@iscte-iul.pt | www.dinamiacet.iscte-iul.pt 
- The expenditures eligible for support, with SI Inovação mainly targeting fixed capital investment, in contrast with the other mechanisms that target less capital intensive investments.

- The main goals of the projects, which are: investments in innovative productive capacity, in the case of SI Inovação; internationalization-related efforts, in the case of SI QPME; access to external knowledge and competences, in the case of Vouchers.

Thus, it is not surprising that SI Inovação has the greatest impact, even when measured in relative terms, on variables such as turnover, exports, number of employees, or the number of workers with higher education, given the substantially larger average amount of support under this scheme and its focus on the expansion of productive capacity for innovative processes/products.

In the same vein, SI QPME shows larger impacts than SI Inovação (and SI QREN as a whole) in export intensity, geographical diversification of exports, and the probability of applying for a trademark. This is consistent with internationalization-related efforts, which are the main goal of SI QPME.

Finally, estimated impacts for the Vouchers are generally not statistically significant (or they are so only marginally) and, when they are, the amount of impacts is substantially lower than for the other incentive systems. These modest results can be explained by the reduced amount of support involved in this policy instrument, as well as the immaterial nature of the expenditures supported by the Vouchers.

\subsection{Heterogeneity of impacts}

In addition to the analysis of global impacts, we also assessed the heterogeneity of impacts of SI QREN according to the following dimensions ${ }^{13}$ : (broad) industry group, firm size, firm age, export intensity, technological/knowledge intensity of the corresponding industry, number of workers with higher education, firm productivity, access to other policy instruments, and support intensity. We only mention here those cases for which we were able to find adequate control groups.

\footnotetext{
13 For this purpose, continuous variables were transformed in categorical variables and the estimations were produced for each category separately. Specifically in the case of firm size, we used the EU classification of micro, small, medium and large firms.
}

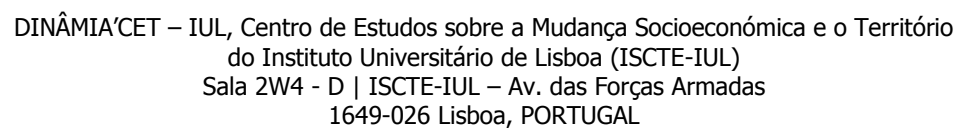


- Heterogeneity of impacts by industry. In the analysis by industry group we found that the impacts of SI QREN are stronger in the case of manufacturing (when compared to the overall results) in terms of absolute values of GVA, exports and R\&D expenditure, reflecting higher starting values of those variables. By contrast, the impacts of SI QREN in this industry group are slightly weaker with regard to employment and human capital variables.

- Heterogeneity of impacts by firm size. The results suggest that the impact of SI QREN on absolute variables (e.g., investment, exports, R\&D expenditures, number of employees, number of workers with higher education, etc.) are stronger for large firms, as expected. However, when measured in relative terms, the impacts become weaker as the average size of the firms grow.

- Heterogeneity of impacts by export intensity. SI QREN seems to produce greater effects in the case of firms with intermediate levels of export intensity (i.e., where exports represent between $10 \%$ and $50 \%$ of turnover). This conclusion is all the more relevant since average amount of support and the average size of these firms are lower than those of firms for which external markets represent more than half of turnover.

- Heterogeneity of impacts by productivity and human capital. The impacts of SI QREN are slightly higher for most variables measured in absolute values in companies with intermediate levels of productivity and human capital (proxied by the number of workers with higher education). This is mainly explained by differences in the pre-treatment values of those variables and by the average amount of support, which tend to be higher in the case of more productive companies with more highly educated employees. In fact, when the relative impacts are considered, the impacts are higher for companies in the lower categories of those variables (i.e., less productive and less human capital-intensive firms), with one important qualification: for firms that have no employee with a university degree, the estimated impacts of SI QREN on productivity or R\&D activities are statistically non-significant, or significant but negative; this result suggests that the subsidies only have positive effects on the firms that have minimum pre-treatment levels of absorptive capacity (using the concept put forward by Cohen e Levinthal, 1990).

- Heterogeneity of impacts by "PME Leader" status. The results obtained for firms that do not have the PME Leader status are similar to those of the total companies under analysis, the most significant difference being that they have a statistically significant impact on financial

\footnotetext{
DINÂMIA'CET - IUL, Centro de Estudos sobre a Mudança Socioeconómica e o Território

do Instituto Universitário de Lisboa (ISCTE-IUL)

Sala 2W4 - D | ISCTE-IUL - Av. das Forças Armadas

1649-026 Lisboa, PORTUGAL

Tel. (+351) 210464031 / 210464197 | E-mail: dinamia@iscte-iul.pt | www.dinamiacet.iscte-iul.pt
} 
autonomy and overall liquidity. Given that the PME Leader status typically allows firms to have access to external finance at more favourable conditions, this result suggests that SI QREN does have a positive impact in the financial situation of those firms who face higher barriers to external finance. ${ }^{14}$

- Heterogeneity of impacts by access to credit lines. The estimated impact of SI QREN on GFCF (and also on value added) is lower in the case of firms that also benefited from credit lines. This suggests that SI QREN produced smaller impacts on firms that have easier access to external finance. This seems to confirm the intuition that direct subsidies and credit lines are partially substitutes in promoting GFCF. However, firms benefiting from both types of support show statistically significant results (in contrast to firms that did not access credit lines) on investment in intangible assets and $R \& D$ expenditures. This suggests that subsidies and credit lines may be complements in promoting more immaterial forms of investment.

- Heterogeneity of impacts by intensity of support. The impacts of SI QREN are higher in the case of firms for which public support represents less than $50 \%$ of the eligible costs of the investment projects - as compared to firms benefiting from higher support intensity. This applies to several output variables, such as: GFCF, value added, exports, number of employees, workers with higher education, and $R \& D$ expenditures. The differential impact is to some extent determined by the pre-treatment levels of the output variables, which tend to be higher for firms benefiting from lower support intensity (put differently, larger firms tend to benefit from lower levels of support intensity, due to regulatory constraints). In the specific case of exports, however, the impacts are substantially higher for lower intensities of support, even when measured in relative terms. This suggests that public support may be more costeffective in promoting exports by reducing the intensity of support.

\subsection{Sustainability of impacts}

The previous subsection reported the impacts estimated at $t+2$, that is, in the end of the third year after the start of the investment project. We have produced estimations of impacts for the comparable cohorts of firms in different time horizons - namely, from $t+3$ to $t+5$ - in order to access the sustainability of policy impacts on firm performance over time.

\footnotetext{
${ }^{14}$ Remember that, according to the results for the whole set of treated firms, SI QREN does not seem to have any impact on the financial situation of firms. 
The results suggest that the effects of SI QREN remain positive several years after the start of the projects, although the estimated impact size varies over the time horizon considered.

Table 8 - Estimated impacts in absolute and relative terms for a selection of outcome variables

\begin{tabular}{|c|c|c|c|}
\hline & $t+3$ & $t+4$ & $t+5$ \\
\hline Gross fixed capital formation & $200,854 € * *$ & $202,834 € * * *$ & $160,521 € * * *$ \\
\hline Gross value added & $538,283 € * * *$ & $672,222 € * * *$ & $367,198 € * *$ \\
\hline Turnover & $2,213,923 € * * *$ & $2,525,418 € * * *$ & $2,417,324 € * * *$ \\
\hline Productivity & $1,822 € * * *$ & $2,911 € * *$ & $3,512 € * * *$ \\
\hline Net profit & $466,697 € * * *$ & $650,938 € * * *$ & $280,755 € * * *$ \\
\hline$R \& D$ expenditures & $73,490 € * * *$ & $99,733 € * * *$ & $100,988 € * * *$ \\
\hline Exports & $1,262,265 € * * *$ & $1,429,194 € * * *$ & $1,521,546 € * * *$ \\
\hline Diversification of exports & 3.1 p.p. $* * *$ & 3.8 p.p. ${ }^{* * *}$ & 3.9 p.p. $* * *$ \\
\hline Export intensity & $0.05 * * *$ & $0.06 * * *$ & $0.06 * * *$ \\
\hline Market share of turnover & 0.03 p.p. ${ }^{* * *}$ & 0.04 p.p. ${ }^{* * *}$ & 0.03 p.p. ${ }^{* * *}$ \\
\hline Probability of patent application & 2.0 p.p. $* * *$ & 1.4 p.p. $* * *$ & 2.2 p.p. $* * *$ \\
\hline Probability of trademark application & 4.3 p.p. $* * *$ & 4.2 p.p. $* * *$ & 2.2 p.p. $* * *$ \\
\hline Probability of obtaining a new certification & 8.6 p.p. $* * *$ & 5.8 p.p. $* * *$ & 4.3 p.p. $* * *$ \\
\hline N. of employees & $9.4^{* * *}$ & $11.5^{* * *}$ & $11.7^{* * *}$ \\
\hline N. of workers with a university degree & $2.2 * * *$ & $3.1 * * *$ & $3.2 * * *$ \\
\hline N. of workers with permanent contracts & $3.9 * * *$ & $5.9 * * *$ & $6.4^{* * *}$ \\
\hline Average wages & $15.16 € *$ & $21.24 € * *$ & $13.99 €$ \\
\hline Gender wage gap & $-15.17 €$ & $-8.67 €$ & $0.30 €$ \\
\hline Intensity of fuel use & $-0.01 * *$ & $-0.02 * * *$ & 0.01 \\
\hline
\end{tabular}

Note: The results presented I the table were produced using the MDM method. The asterisks correspond to the p-value of each estimate $(* * *<0.01 ; * *<0.05 ; *<0.1)$.

The positive impacts of SI QREN on GFCF are more significant during the execution of the supported projects, decreasing in the subsequent period. These results suggest that part of the effect of public support consists in the anticipation of investment decisions by firms, which would tend to carry them out later if they had not benefited from public support. In any case, at the end of the sixth year after the start of the project (i.e., $t+5$ ), treated firms continue to have higher levels cumulative investment than non-treated ones, suggesting that SI QREN has a sustained impact on business investment.

For some other variables, the impact of SI QREN not only remains positive over the years, but actually grows over time (at least in the time horizon considered here). This is the case of productivity, exports, R\&D expenditures, number of employees, number of workers with a university degree, and number of workers with permanent contracts.

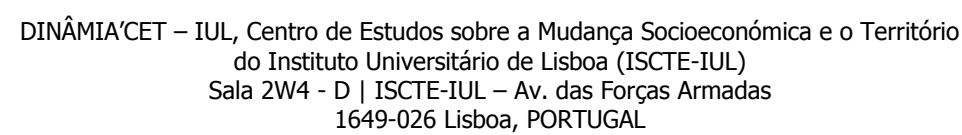


Regarding the variables related to the use of industrial property and the certification of management systems, the impact of the incentive systems remains positive and statistically significant at the end of the sixth year after the start of the project, although there is no increase in the impact over time.

\subsection{Cost-effectiveness and additionality}

Cost-effectiveness is here measured by the ratio between the average amount of support and the estimated average impact. The value of this ratio can be interpreted as the amount of euros that was required to induce a unit variation in output variable (assuming that the estimated impact is entirely attributable to the policy effect).

Small variations in the estimated average impact value can lead to large fluctuations in the value of the cost-effectiveness ratio, especially when the absolute values of the impacts are very small compared to the amount of support. Therefore, we only consider here those impacts for which the statistical significance of the estimates is high ( $p$-value $<0.01$ ).

According to our results, in order to induce an additional increase of one euro in GFCF (in each supported firm after three years) SI QREN has to provide an amount of support of 0.71 euros. The corresponding cost-effectiveness is 1.79 euros for GVA, 1.49 euros for net profits, 1.17 euros for exports and 17.41 euros for $R \& D$ expenses. Our results also show that an average of around 82,000 euros are required to induce the creation of an additional job in each firm, and around 416,000 euros to induce a net growth of one highly educated worker.

Compared to the average of the SI QREN, the amount of incentive needed to induce a unit of impact is greater in the case of manufacturing, micro and small enterprises. It is also more costly to induce an additional euro of exports in companies with reduced export intensity. In general, cost-effectiveness is greater in companies with reduced or intermediate levels of productivity.

The amount of public fund needed to induce the same levels of impacts is generally smaller for companies that are not PME Leaders. For firms benefiting from credit lines it becomes more costly for public funds to induce an additional GFCF increase. Both results confirm that the effectiveness of SI QREN is generally greater when it targets firms that face higher barriers in obtaining external finance.

\footnotetext{
DINÂMIA'CET - IUL, Centro de Estudos sobre a Mudança Socioeconómica e o Território

do Instituto Universitário de Lisboa (ISCTE-IUL)

Sala 2W4 - D | ISCTE-IUL - Av. das Forças Armadas

1649-026 Lisboa, PORTUGAL

Tel. (+351) 210464031 / 210464197 | E-mail: dinamia@iscte-iul.pt | www.dinamiacet.iscte-iul.pt
} 
A related concept is additionality, which is obtained by dividing the estimated average impact of SI QREN on GFCF by the average amount of support (i.e., it corresponds to the additional amount of investment associated with each euro of support). The additionality of SI QREN after three years is 1.41 euros (according to the MDM method). In other words, for each euro of public support the beneficiary firms have invested more 1.41 euros in fixed capital than they would have invested otherwise. The additionality effect is higher than the average in the case firms with intermediate levels of export intensity (i.e. between 10\% and 50\%). By contrast, additionality is particularly low in firms that have also benefited from credit lines.

DINÂMIA'CET - IUL, Centro de Estudos sobre a Mudança Socioeconómica e o Território do Instituto Universitário de Lisboa (ISCTE-IUL)

Sala 2W4 - D | ISCTE-IUL - Av. das Forças Armadas

1649-026 Lisboa, PORTUGAL 


\section{CONCLUSIONS AND POLICY RECOMMENDATIONS}

The goal of this research was to estimate the impact of SI QREN - a set of enterprise support mechanisms, in the form of grants and soft loans, that were in place in Portugal between 2007 and 2013 - on various dimensions of firm performance. For this purpose, we used an unprecedented set of firm-level information, gathered from different institutional sources. This information not only allowed for a detailed analysis of the characteristics of firms benefiting from public support, but also provided favourable conditions for a rigorous analysis of the impact of these policy instruments on the beneficiaries' performance.

The analysis of a wide range of indicators confirmed that the firms that were supported by SI QREN are systematically different from non-treated firms. In particular, we find that SI QREN selects positively: firms from the Norte and Centro regions, manufacturing firms and knowledge-based services, and companies with 10 or more employees. Regardless of industry, firm size, or location, SI QREN is biased towards the most sophisticated and financially robust firms. Those ex ante differences between treated and non-treated firms reflect both the selective rules governing the access of firms to SI QREN's support, as well as different firms' propensities to apply (self-selection).

In order to address the selection bias that is inherent to the policy under analysis we estimated the impacts using the bias corrected matching estimator put forward by Abadie and Imbens $(2002,2011)$, producing results based on both the Propensity-Score Matching and Malahanobis Distance Matching methods, for robustness purposes.

The results obtained suggest that SI QREN contributed to the performance of firms in domains such as: investment in fixed capital, human capital, innovation, internationalization, and competitiveness. More specifically, the estimated impacts of SI QREN are positive and statistically significant for variables such as: GFCF, number of employees, value added, turnover, number of skilled workers, employees with a university degree, $R \& D$ expenditures, $R \& D$ staff, use of patents, trademarks and other forms and industrial property, certification of management systems, exports, export intensity, export diversification, productivity, and net profits. Generally speaking, the impacts of SI QREN remain positive and statistically significant in the mid-term, after the supported projects have been completed.

Thus, we conclude that SI QREN accomplished its main policy goals, as they were identified in the theory of change of the policy. We also find that SI QREN had a positive impact on other dimensions

\footnotetext{
DINÂMIA'CET - IUL, Centro de Estudos sobre a Mudança Socioeconómica e o Território

do Instituto Universitário de Lisboa (ISCTE-IUL)

Sala 2W4 - D | ISCTE-IUL - Av. das Forças Armadas

1649-026 Lisboa, PORTUGAL

Tel. (+351) 210464031 / 210464197 | E-mail: dinamia@iscte-iul.pt | www.dinamiacet.iscte-iul.pt
} 
of firm performance that do not emerge clearly from the theory of change, but which are often referred to as relevant policy goals, in particular job quality and average wages. As regards ecoefficiency and gender equality, we found evidence of modest positive impacts when analysing specific groups of firms, but not for the overall set of beneficiaries.

Contrarily to what was suggested by the theory of change of the policy, we found no consistent impacts of SI QREN on firms' financial situation. These results do not stem from the absence of any effects, but rather from the large variability of the estimated impacts across firms. This may be explained by the fact that the amount of support is often modest when compared to the firms' assets.

In general, the above mentioned results for SI QREN, when considered as a whole, are valid for each of the three support mechanisms under analysis (SI Inovação, SI QPME, and the Vouchers). Most of the differences found in the impacts of each mechanism are explained by - and coherent with - the characteristics of the firms targeted by each mechanism the average amount of support, and the type of eligible expenditures.

By assessing the heterogeneity of impacts, we conclude that the policy has greater absolute impacts but lower relative impacts (with regard to the pre-treatment levels of the output variables) for larger firms. In other words, although the change produced by SI QREN in the overall economy is greater when the supported projects are conducted by larger companies, it tends to induce more transformations at the firm level when the projects are conducted by smaller firms.

We also find that the impacts of SI QREN on fixed investment are lower in the case of companies that also benefited from credit lines (another form of public support, which allows firms to access bank credit at lower costs). This suggests that SI QREN is less effective for inducing additional investment in firms that have easier access to external finance. However, firms benefiting from both types of support (incentives and credit lines) show statistically significant results (in contrast to firms that did not access credit lines) on investment in intangible assets and $R \& D$ expenditures. This suggests that subsidies and credit lines complement each other in promoting more immaterial factors of competitiveness.

The aforementioned results lead us to put forward the following policy recommendations. First, the general principles and selection criteria underlying SI QREN should remain unchanged, since the policy has been producing the desired goals, with each specific support mechanism showing impacts that are differentiated according to what was envisaged by the design of the policy. Second, the authorities should adjust the generosity of support to the financial situation of companies; by reducing

\footnotetext{
DINÂMIA'CET - IUL, Centro de Estudos sobre a Mudança Socioeconómica e o Território

do Instituto Universitário de Lisboa (ISCTE-IUL)

Sala 2W4 - D | ISCTE-IUL - Av. das Forças Armadas

1649-026 Lisboa, PORTUGAL

Tel. (+351) 210464031 / 210464197 | E-mail: dinamia@iscte-iul.pt | www.dinamiacet.iscte-iul.pt
} 
incentive rates for companies with easier access to bank credit (and other forms of financing), resources could be freed up to support promising business projects aligned with public policy priorities, which face greater difficulties in financing. Finally, there should be a broad debate on the possible inclusion of selection criteria related to the quality of jobs created, intra-firm income distribution, gender equality and eco-efficiency; these purposes are mentioned as policy goals in various official documents and are partially promoted by SI QREN; further advances in those domains could benefit from their inclusion as explicit goals of enterprise support policies in Portugal.

DINÂMIA'CET - IUL, Centro de Estudos sobre a Mudança Socioeconómica e o Território do Instituto Universitário de Lisboa (ISCTE-IUL)

Sala 2W4 - D | ISCTE-IUL - Av. das Forças Armadas

1649-026 Lisboa, PORTUGAL

Tel. (+351) 210464031 / 210464197 | E-mail: dinamia@iscte-iul.pt | www.dinamiacet.iscte-iul.pt 


\section{REFERENCES}

Abadie, A.; Drukker, D.; Herr, J. L. \& Imbens, G. W. (2004). "Implementing matching estimators for average treatment effects in Stata", The Stata Journal 4 (3), 290-311.

Abadie, A. \& Imbens, G.W. (2006). "Large Sample Properties of Matching Estimators for Average Treatment Effects" . Econometrica, 74 (1), 235-267.

Athey, S. \& Imbens, G.W. (2017). "The State of Applied Econometrics: Causality and Policy Evaluation". Journal of Economic Perspectives, 31(2), 3-32.

Battistin, E. \& Rettore, E. (2008). "Ineligibles and eligible non-participants as a double comparison group in regression-discontinuity designs". Journal of Econometrics, 142, pp. 715-730.

Bernini, C. \& Pellegrini, G. (2011). "How are growth and productivity in private firms affected by public subsidy? Evidence from a regional policy". Regional Science and Urban Economics, 41, pp. 253-265.

Bia, M. \& Mattei, A. (2012). "Assessing the effect of the amount of financial aids to Piedmont firms using the generalized propensity score". Statistical Methods and Applications, 21, pp. 485-516.

Bondonio, D. \& Greenbaum, R. T. (2006). "Do Business Investment Incentives Promote Employment in Declining Areas? Evidence from EU Objective-2 Regions". European Urban and Regional Studies, 13, pp. 225-244.

Bondonio, D. \& Martini, A. (2012). Counterfactual impact evaluation of cohesion policy: impact and cost-effectiveness of investment subsidies in Italy. Final Report to DG Regional Policy.

Bondonio, D.; Fernandes, T.F. \& Mamede, R. (2016). "Does EU Public Support to Firm Investments Boost High Quality Jobs? Evidence from Linked Employer-Employee Microdata and NaturalExperiment Conditions”, Working Paper do Dinâmia'CET 2016/01.

Bronzini, R. \& de Blasio, G. (2006). "Evaluating the impact of investment incentives: The case of Italy's Law 488/1992”, Journal of Urban Economics, Vol. 60, pp. 327-349.

Brousselle, A. \& Champagne, F. (2011). "Program Theory Evaluation: Logic Analysis". Evaluation and Program Planning, 34(1), pp. 69-78.

\footnotetext{
DINÂMIA'CET - IUL, Centro de Estudos sobre a Mudança Socioeconómica e o Território

do Instituto Universitário de Lisboa (ISCTE-IUL)

Sala 2W4 - D | ISCTE-IUL - Av. das Forças Armadas

1649-026 Lisboa, PORTUGAL

Tel. (+351) 210464031 / 210464197 | E-mail: dinamia@iscte-iul.pt | www.dinamiacet.iscte-iul.pt
} 
Cerqua, A. \& Pellegrini, G. (2014). “Do subsidies to private capital boost firms' growth? A multiple regression discontinuity design approach?”, Journal of Public Economics, Vol. 109, pp. 114-126.

Cohen, W. \& Levinthal, D. (1990). "Absorptive Capacity: A New Perspective on Learning and Innovation". Administrative Science Quarterly, 35 (1), 128-152.

Coryn, C.; Noakes, L.; Westine, C. \& Schröter, D. (2011). "A systematic review of theory-driven evaluation practice from 1990 to 2009". American Journal of Evaluation, 32(2), pp. 199-226.

Criscuolo, C.; Martin, R.; Overmann, H. \& Van Reenen, J. (2012). "The Causal Effects of an Industrial Policy", NBER Working Paper Series (retrieved from http://www.nber.org/papers/w17842).

Edler, J. \& Fagerberg, J. (2017). "Innovation policy: What, why, and how". Oxford Review of Economic Policy, 33 (1), 2-23.

Funnell, S. \& Rogers, P. (2011). Purposeful Program Theory: Effective Use of Theories of Change and Logic Models. New York: John Wiley \& Sons.

Greenbaum, R. T. \& Bondonio, D. (2014). “Community Resilience to Rare Events: Using Dynamic Propensity Score Matching to Examine the Effects of Disasters", Paper Prepared for the 61st North American Meetings of the Regional Science Association International.

Hirano K. \& Imbens G. (2004). "The propensity score with continuous treatment”. In Gelman and Meng (eds.), Applied Bayesian modeling and causal inference from missing data perspective. New York: Wiley.

Ho, D. E., Imai, K., King, G. \& Stuart, E. A. (2007). "Matching as Nonparametric Preprocessing for Reducing Model Dependence in Parametric Causal Inference”, Political Analysis, 15, pp. 199-236.

Iacus, S. M.; King, G. \& Porro, G. (2011). “Causal Inference without Balance Checking: Coarsened Exact Matching”. Political Analysis, 20, pp. 1-24.

Iacus, S.M.; King, G. \& Porro, G. (2012). "Causal Inference without Balance Checking: Coarsened Exact Matching". Political Analysis, 20 (1), 1-24.

Imai, K., \& Van Dyk, D. A. (2004). "Causal inference with general treatment regimes: Generalizing the propensity score”. Journal of the American Statistical Association, 99(467), 854-866.

\footnotetext{
DINÂMIA'CET - IUL, Centro de Estudos sobre a Mudança Socioeconómica e o Território

do Instituto Universitário de Lisboa (ISCTE-IUL)

Sala 2W4 - D | ISCTE-IUL - Av. das Forças Armadas

1649-026 Lisboa, PORTUGAL

Tel. (+351) 210464031 / 210464197 | E-mail: dinamia@iscte-iul.pt | www.dinamiacet.iscte-iul.pt
} 
Imbens, G. (2000). "The role of Propensity score in estimating dose -response functions". Biometrika $87,706-710$.

Imbens, G. W. \& Rubin, D. (2015). Causal Inference for Statistics, Social, and Biomedical Sciences: An Introduction. Cambridge University Press.

Imbens, G.W. \& Wooldridge, JM (2009). "Recent developments in the econometrics of program evaluation". Journal of Economic Literature, 47 (1), 5-86.

Imbens, G.W. (2015). "Matching methods in practice: Three examples". Journal of Human Resources, 50 (2), 373-419.

King, G.; Nielsen, R.; Coberley, C. \& Pope, J. E. (2011). "Comparative Effectiveness of Matching Methods for Causal Inference". Unpublished manuscript.

Koski, H. \& Pajarinen, M. (2013). "The role of business subsidies in job creation of start-ups, gazelles and incumbents", Small Business Economics, 41, pp. 195-214.

Lechner, M. (2001). "Identification and estimation of causal effects of multiple treatments under the conditional independence assumption". In Lechner and Pfeiffer (eds.), Econometric evaluations of active labor market policies in Europe. Heidelberg: Physica/Springer.

Lechner, M. (2002). "Program heterogeneity and propensity score matching: an application to the evaluation of active labor market policies". The Review of Economics and Statistics, 84(2), 205-220.

Lee, D. S. \& Lemieux, T. (2010). "Regression Discontinuity Designs in Economics", Journal of Economic Literature, 48, pp. 281-355.

Mamede, R.P.; Fernandes, T. \& Silva, A.A. (2013), "Análise contrafactual dos impactos dos incentivos do POE/PRIME na sobrevivência e no crescimento das empresas", e+cadernos 05:2013, Observatório do QREN.

Mouqué, D. (2012). "What are counterfactual impact evaluations teaching us about enterprise and innovation support". Regional Focus 2.

\footnotetext{
DINÂMIA'CET - IUL, Centro de Estudos sobre a Mudança Socioeconómica e o Território

do Instituto Universitário de Lisboa (ISCTE-IUL)

Sala 2W4 - D | ISCTE-IUL - Av. das Forças Armadas

1649-026 Lisboa, PORTUGAL

Tel. (+351) 210464031 / 210464197 | E-mail: dinamia@iscte-iul.pt | www.dinamiacet.iscte-iul.pt
} 


\section{ANNEXES}

Table A.1 - Definition of outcome variables

\begin{tabular}{|c|c|c|c|}
\hline $\begin{array}{l}\text { Dimensions of } \\
\text { performance }\end{array}$ & Result variable & Formula / description & Source \\
\hline \multirow{2}{*}{ Investment } & GFCF & GFCF & SCIE (INE) \\
\hline & Intangible investment & Intangible investment & SCIE (INE) \\
\hline \multirow{4}{*}{$\begin{array}{l}\text { Financial } \\
\text { situation }\end{array}$} & Financial autonomy & Equity / Assets & SCIE (INE) \\
\hline & Coverage of interest charges & Operating Income / Interest & SCIE (INE) \\
\hline & Cost of financing obtained & Interest paid / Financing obtained & SCIE (INE) \\
\hline & General Liquidity & Current Assets / Current Liabilities & SCIE (INE) \\
\hline \multirow{4}{*}{ Qualifications } & No. of workers with higher education & Workers with a Bachelor's degree or higher & QP (MTSSS) \\
\hline & $\begin{array}{l}\text { No. of administrators with higher } \\
\text { education }\end{array}$ & $\begin{array}{l}\text { Administrators with a level of education equal } \\
\text { to or higher than baccalaureate }\end{array}$ & QP (MTSSS) \\
\hline & No. of S\&T workers & $\begin{array}{l}\text { Workers with CNP codes 211, 212, 213, 214, } \\
221 \text { and } 222\end{array}$ & $\begin{array}{r}\text { IPCTN } \\
\text { (DGEEC) }\end{array}$ \\
\hline & No. of skilled workers & Workers with qualification levels 1,2 or 3 & QP (MTSSS) \\
\hline \multirow{8}{*}{ Innovation } & Expenditure on R\&D & Expenditure on R\&D & $\begin{array}{r}\text { IPCTN } \\
\text { (DGEEC) }\end{array}$ \\
\hline & Intensity of R\&D in GVA & Expenditure on R\&D/GVA & SCIE (INE) \\
\hline & Intensity of R\&D in turnover & Expenditure on R\&D/Turnover & SCIE (INE) \\
\hline & R\&D staff & R\&D staff & $\begin{array}{r}\text { IPCTN } \\
\text { (DGEEC) } \\
\end{array}$ \\
\hline & Patent applications ${ }^{(*)}$ & Annual national patent applications & INPI \\
\hline & Trademark applications ${ }^{(*)}$ & Annual national trademark applications & INPI \\
\hline & Design applications ${ }^{(*)}$ & Annual applications for national designs & INPI \\
\hline & New certifications $\left.{ }^{*}\right)$ & New management system certifications & IPAC \\
\hline \multirow{6}{*}{$\begin{array}{l}\text { Internatio } \\
\text { lization }\end{array}$} & Geographical diversification of exports & Exports from outside the EU/Turnover & SCIE (INE) \\
\hline & Exports & Exports to EU + Exports to EU & $\begin{array}{r}\text { BD Foreign } \\
\text { Markets (INE) }\end{array}$ \\
\hline & Exports extra-EU & Sales and services on the non-EU market & $\begin{array}{r}\text { BD Foreign } \\
\text { Markets (INE) }\end{array}$ \\
\hline & Exports to the EU & Sales and services on the Community market & $\begin{array}{r}\text { BD Foreign } \\
\text { Markets (INE) }\end{array}$ \\
\hline & Imports & Purchases and Supplies in the external market & $\begin{array}{r}\text { BD Foreign } \\
\text { Markets (INE) }\end{array}$ \\
\hline & Export Intensity & Exports/Turnover & SCIE (INE) \\
\hline
\end{tabular}

DINÂMIA'CET - IUL, Centro de Estudos sobre a Mudança Socioeconómica e o Território

do Instituto Universitário de Lisboa (ISCTE-IUL)

Sala 2W4 - D | ISCTE-IUL - Av. das Forças Armadas

1649-026 Lisboa, PORTUGAL

Tel. (+351) 210464031 / 210464197 | E-mail: dinamia@iscte-iul.pt | www.dinamiacet.iscte-iul.pt 
The impact of EU-funded direct subsidies on several dimensions of firm performance in Portugal: 2008-2015

\begin{tabular}{|c|c|c|c|}
\hline $\begin{array}{l}\text { Dimensions of } \\
\text { performance }\end{array}$ & Result variable & Formula / description & Source \\
\hline & Direct insertion in international trade & (Exports+Imports)/VABcf & SCIE (INE) \\
\hline \multirow{3}{*}{ Growth } & No. of employees & No. of employees & SCIE (INE) \\
\hline & Gross added value & Gross added value & SCIE (INE) \\
\hline & Turnover & Turnover & SCIE (INE) \\
\hline \multirow{7}{*}{$\begin{array}{l}\text { Competi - } \\
\text { tiveness }\end{array}$} & Degree of transformation of production & GVA/Production & SCIE (INE) \\
\hline & Productivity & GVA/No. of employees & SCIE (INE) \\
\hline & Market share of turnover & $\begin{array}{l}\text { Turnover of the firm/Turnover of the industry } \\
\text { (NACE } 3 \text { digit level) }\end{array}$ & SCIE (INE) \\
\hline & Return of Turnover & Net profit/Turnover & SCIE (INE) \\
\hline & Return on equity & Net profit /Equity & SCIE (INE) \\
\hline & Return on assets & Net profit / Total Assets & SCIE (INE) \\
\hline & Net profit & Net profit & SCIE (INE) \\
\hline \multirow{3}{*}{ Eco-efficiency } & Intensity of use of water & Water-related expenditure / GVA & SCIE (INE) \\
\hline & Intensity of fuel use & Fuel-related expenditure / GVA & SCIE (INE) \\
\hline & Intensity of electricity use & Electricity-related expenditure / GVA & SCIE (INE) \\
\hline \multirow{3}{*}{$\begin{array}{l}\text { Quality of } \\
\text { employment }\end{array}$} & $\begin{array}{l}\text { No. of workers with permanent } \\
\text { contracts }\end{array}$ & No. of workers with permanent contracts & QP (MTSSS) \\
\hline & Impact of temporary contracts & $\begin{array}{l}\% \text { of workers who do not have permanent } \\
\text { contracts }\end{array}$ & QP (MTSSS) \\
\hline & Incidence of atypical work duration & $\begin{array}{l}\% \text { of employees with normal work periods } \\
\text { below } 32 \text { or above } 48\end{array}$ & QP (MTSSS) \\
\hline \multirow{6}{*}{$\begin{array}{l}\text { Income } \\
\text { distribution }\end{array}$} & Wage dispersion & Coefficient of variation of wages & QP (MTSSS) \\
\hline & Incidence of minimum wage & $\begin{array}{l}\% \text { of employees earning the national minimum } \\
\text { wage }\end{array}$ & QP (MTSSS) \\
\hline & Annual average staff costs & Expenses with staff/staff & SCIE (INE) \\
\hline & Average monthly wages & Sum of wages/No. of employees & QP (MTSSS) \\
\hline & Weight of wage costs in GVA & Wage costs/GVA & SCIE (INE) \\
\hline & $\begin{array}{l}\text { Weight of Board of Directors on total } \\
\text { wage costs }\end{array}$ & Remuneration of the Board/Total wage costs & SCIE (INE) \\
\hline \multirow{3}{*}{ Gender equality } & № of women in the administration & $\begin{array}{l}\text { No. of female members in the board of } \\
\text { directors }\end{array}$ & QP (MTSSS) \\
\hline & Percentage of Women & No. of women/Total number of employees & QP (MTSSS) \\
\hline & Gender pay gap & $\begin{array}{l}\text { (Average wages of women) - (Average wages of } \\
\text { men) }\end{array}$ & QP (MTSSS) \\
\hline
\end{tabular}

${ }^{(*)}$ In the case of the variables relating to industrial property applications or to the certification of management systems, the results are expressed as a probability, corresponding to the difference between the proportion of treated and non-treated firms that applied for IP/obtained a certification.

DINÂMIA'CET - IUL, Centro de Estudos sobre a Mudança Socioeconómica e o Território

do Instituto Universitário de Lisboa (ISCTE-IUL)

Sala 2W4 - D | ISCTE-IUL - Av. das Forças Armadas

1649-026 Lisboa, PORTUGAL

Tel. (+351) 210464031 / 210464197 | E-mail: dinamia@iscte-iul.pt | www.dinamiacet.iscte-iul.pt 